Mesozoic Stratigraphy of the

Patagonia Mountains and

Adjoining Areas,

Santa Cruz County, Arizona

GEOLOGIGAL SURVEY PROFESSIONAL PAPER 658-E

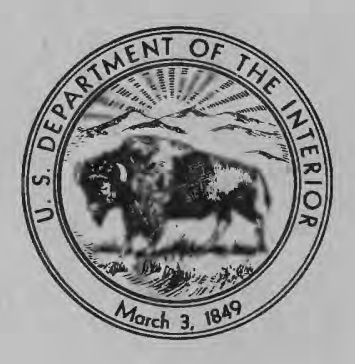




\section{Mesozoic Stratigraphy of the}

Patagonia Mountains and

\section{Adjoining Areas,}

\section{Santa Cruz County, Arizona}

By FRANK S. SIMONS

MESOZOIC STRATIGRAPHY IN SOUTHEASTERN ARIZONA

GEOLOGICAL SURVEY PROFESSIONAL PAPER 658-E

Descriptive stratigraphy of Triassic, Jurassic, and Cretaceous rocks that are mainly rhyolites but that include some sedimentary rocks and intermediate volcanic rocks

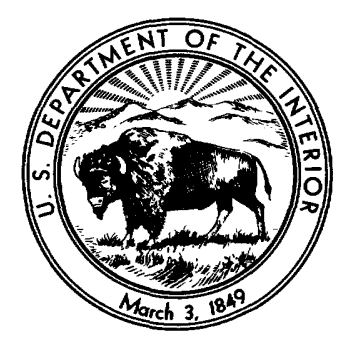




\section{UNITED STATES DEPARTMENT OF THE INTERIOR \\ ROGERS C. B. MORTON, Secretary \\ GEOLOGICAL SURVEY}

W. A. Radlinski, Acting Director

For sale by the Superintendent of Documents, U.S. Government Printing Office Washington, D.C. 20402 - Price 40 cents (paper cover) Stock Number 2401-1205 


\section{CONTENTS}

Abstract

Introduction

Triassic and Jurassic rocks

Canelo Hills Volcanics

Triassic or Jurassic rocks

Volcanic rocks in the southern Patagonia

Mountains

UX Ranch block

Duquesne block

Corral Canyon block

Volcaniclastic sequence

Volcanic sequence.

American Mine block

Thunder Mine block

Chemical composition.

Age and correlation

Volcanic and sedimentary rocks

in the Flux mine area

\begin{tabular}{|c|c|}
\hline Page & \\
\hline E1 & Cretaceous rocks. \\
\hline 1 & Bisbee Formation \\
\hline 2 & Fossils and age \\
\hline 2 & Volcanic rocks of lower Alum Gulch \\
\hline 3 & Volcanic rocks of Dove Canyon \\
\hline 3 & $\begin{array}{l}\text { Trachyandesite of Meadow Valley } \\
\text { Tuff and shale }\end{array}$ \\
\hline 3 & Thin lava flows \\
\hline 3 & Thick lava flows \\
\hline 6 & Chemical composition \\
\hline 6 & Alteration of trachyandesitic lavas \\
\hline 7 & Age \\
\hline 8 & Cretaceous or Tertiary rocks \\
\hline 9 & Volcanic rocks of the Humboldt \\
\hline 9 & mine-Trench Camp area \\
\hline 10 & Volcanic rocks of Red Mountain \\
\hline & arences \\
\hline
\end{tabular}

12
Page

E13

13

18

18

20

20

21

\section{ILLUSTRATIONS}

FIGURE 1. Index map of part of southeastern Arizona

2. Generalized geologic map and sections of part of the Patagonia Mountains and Canelo Hills

3. Sketch of a partial section of volcanic and sedimentary rocks of the UX Ranch block north of the Kansas mine

4. Sketch of a partial section of sedimentary and epiclastic volcanic rocks in the lower part of the Bisbee Formation west of the UX Ranch

5. Sketch of a geologic section of volcanic and sedimentary rocks of the trachyandesite of Meadow Valley along a gully northeast of the Little Outfit Ranch.

\section{TABLES}

TABLE 1. Comparison of chemical analyses, norms, and semiquantitative spectrographic analyses of Mesozoic volcanic rocks, Patagonia Mountains, with those of associated igneous and Nockolds' average rocks

2. Average chemical analyses of rhyolites and granites, Patagonia Mountains.

3. Comparison of chemical analyses, norms, and semiquantitative spectrographic analyses of trachyandesite and rhyodacite of Meadow Valley with those of Nockolds' average rocks. 


\title{
MESOZOIC STRATIGRAPHY OF THE PATAGONIA MOUNTAINS AND ADJOINING AREAS, SANTA CRUZ COUNTY, ARIZONA
}

\author{
By Frank S. Simons
}

\begin{abstract}
The Patagonia Mountains and Canelo Hills in the Lochiel and Nogales 15-minute quadrangles of southeastern Arizona consist in large part of volcanic and sedimentary rocks of Mesozoic age. These rocks are in fault contact with Precambrian plutonic igneous rocks and overlie or are faulted against Paleozoic sedimentary rocks ranging in age from Cambrian to Permian. They have been intruded by granodiorite of early Tertiary age and are overlain by sedimentary and volcanic rocks of middle Tertiary to Holocene age. At least 75 percent of the Mesozoic stratigraphic column is volcanic, mostly silicic volcanics; the remainder is sedimentary with some interbedded volcanic rocks. The entire section is not exposed in any one area, and correlations between areas and structural blocks are uncertain. The aggregate total thickness is unknown but is at least 10,000 feet and probably is 14,000 to 15,000 feet.
\end{abstract}

Silicic volcanic rocks of probable Triassic or Jurassic age make up several structural blocks in the southern half of the Patagonia Mountains. Correlation between blocks is uncertain, but the thickness of the volcanic sequence is estimated to be at least 6,000 to 7,000 feet and probably is considerably more. Rocks are mostly rhyolitic lava, welded tuff, and tuff interlayered with minor sandstone, conglomerate, and less-silicic volcanic rocks. Most of the Canelo Hills consist of rhyolitic lava and welded tuff very similar to those in the Patagonia Mountains; the lava is at least 1,000 feet thick, and the overlying welded tuff is at least 6,000 feet thick.

Cretaceous rocks consist of several thousand feet of dominantly fine grained sedimentary rocks assigned to the Bisbee Formation of Early Cretaceous age in the central Patagonia Mountains; several thousand feet of dominantly trachyandesitic lava in the northern Patagonia Mountains, upper San Rafael Valley, and Canelo Hills; and at least 2,000 feet of heterogeneous volcanic and sedimentary rocks on the southwest flank of the Canelo Hills. The Bisbee Formation comprises mostly brown siltstone and mudstone with numerous thin limestone beds and some sandstone, conglomerate, and tuffaceous rocks; it rests disconformably on Triassic or Jurassic silicic volcanic rocks. The trachyandesite is perhaps 3,000 feet thick in the Patagonia Mountains, where it lies unconformably either on Triassic or Jurassic volcanic rocks or on about 1,500 feet of rhyolitic to latitic lava and tuff, which in turn rest unconformably on the older volcanies. In the Canelo Hills, where the trachyandesite is much thinner, it is underlain conformably by 1,000 feet or more of tuff, shale, and conglomerate, which are faulted against older volcanic rocks. The volcanic-sedimentary sequence southwest of the Canelo Hills is mainly epiclastic volcanic conglomerate of andesitic composition with some more-silicic tuff and tuffaceous sandstone; some of these rocks resemble those underlying the trachyandesite farther north.

The youngest rocks, of Late Cretaceous or early Tertiary age, are coarse silicic tuff, tuff breccia, and lava west of Trench Camp, where they are at least 800 feet thick, and massive silicic volcanic rocks of uncertain origin on Red Mountain, where the thickness is perhaps 1,500 feet. These rocks lie unconformably on rocks of Late Cretaceous and of Triassic or Jurassic age.

\section{INTRODUCTION}

The Patagonia Mountains, a north-northwesterly trending range lying east of Nogales and south of Patagonia in southeastern Arizona (fig. 1), consist in large part of Mesozoic volcanic and sedimentary rocks. This report describes these rocks, together with some of similar age in nearby parts of the Canelo Hills to the east and in the intervening area at the head of the San Rafael Valley. Figure 2 is a generalized geologic map showing the distribution of these rocks, which range in age from Triassic to Late Cretaceous or early Tertiary. Plutonic igneous rocks of Mesozoic age are also widely represented in the same region but are noted only briefly herein.

The layered rocks comprise six cartographic units of known or strongly inferred Mesozoic age and two units of uncertain but probable Late Cretaceous or early Tertiary age. Some pairs of units may be stratigraphic equivalents but either do not crop out in the same area or are separated by major faults and therefore are described separately. Only partial sections are available for all but one unit, and correlations are uncertain. The aggregate total thickness is unknown; in the Patagonia Mountains this thickness is at least 10,000 feet and probably is as much as 14,000 or 15,000 feet, and in the Canelo Hills it may be 10,000 feet or more. Volcanic 
rocks of silicic to intermediate composition make up 75 percent or more of the Mesozoic stratigraphic column; the remainder is sedimentary rocks and some interlayered volcanic beds.

Fieldwork was done over a period of about 7 months during 1960-63 as part of the geologic mapping of the Lochiel and Nogales 15-minute quadrangles. Office work included microscopic study of about 275 thin sections and X-ray diffractometer analysis of 30 altered rocks. Chemical analyses were made by rapid rock analysis methods (Shapiro and Brannock, 1962) on 14 volcanic rocks and two granites. Various sections of the report have been strengthened by discussions with my colleagues John R. Cooper, Harald Drewes, Philip T. Hayes, and Robert B. Raup, all of whom were working concurrently in adjacent or nearby areas; none, however, should be held responsible for any conclusions reached herein.

\section{TRIASSIC AND JURASSIC ROCKS CANELO HILLS VOLCANICS}

The Canelo Hills Volcanics (fig. 2) were named and described by Hayes, Simons, and Raup (1965) and were further described by Hayes (1970a, p.
A3-A9) ; hence, they will not be discussed here in detail. The formation is divided into three informal members: a lower, volcaniclastic and volcanic member as much as 2,000 feet thick; a middle, rhyolite member at least 1,000 feet thick; and an upper, rhyolitic welded tuff member at least 6,000 feet thick. It is assigned a Late Triassic and Early Jurassic age on the basis of field relations with paleontologically dated rocks of Permian age and of Early Cretaceous age, and on the basis of radiometric ages of $173 \pm 7$ m.y. (million years) determined by the potassium-argon method on biotite from the welded tuff member and $144 \pm 4$ m.y. determined by the same method on biotite from the lower member. The lower member was correlated by Hayes (1970a, p. A8-A9) with the Gardner Canyon Formation of the Santa Rita Mountains (Drewes, 1968, p. C7), for which a radiometric age of $190 \pm 20$ m.y. (Triassic) was obtained by the lead-alpha method on zircon from a dacite. In the area under consideration, the Canelo Hills Volcanics are in fault contact with the trachyandesite of Meadow Valley and the volcanic rocks of Dove Canyon, both of Late Cretaceous age, and are overlain by late Tertiary and Quaternary alluvium.

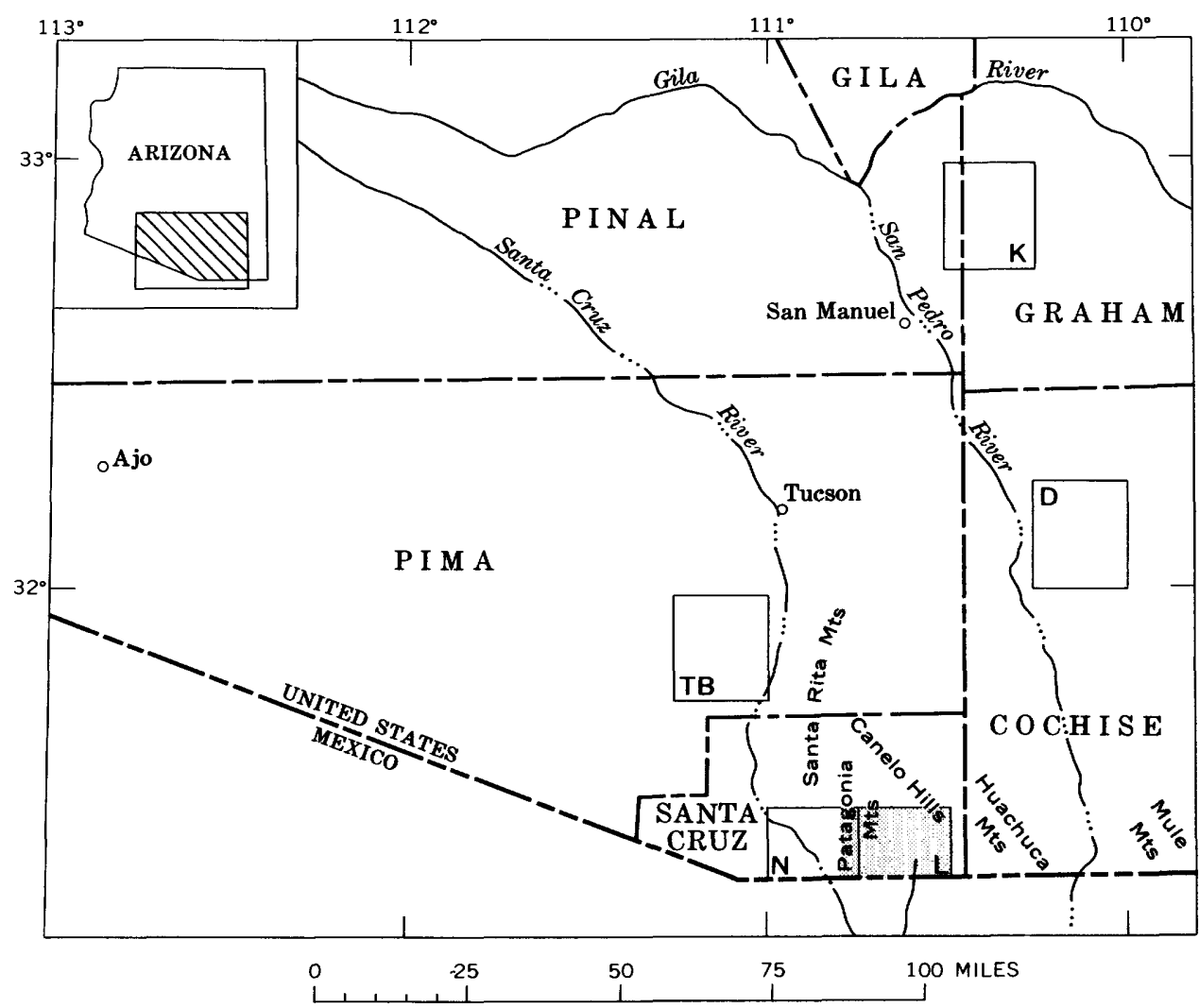

FIGURE 1.-Index map of part of southeastern Arizona, showing Patagonia Mountains and other features mentioned in text. Area of figure 2 shaded. Quadrangles: D, Dragoon; K, Klondyke; L, Lochiel; N, Nogales; TB, Twin Buttes. 
TRIASSIC OR JURASSIC ROCKS

\section{VOLCANIC ROCKS IN THE SOUTHERN PATAGONIA MOUNTAINS}

A sequence of Mesozoic rocks at least 10,000 feet thick occupies an area of about 15 square miles in the south half of the Patagonia Mountains, where they crop out in several blocks separated by faults, some of which are of great magnitude (fig. 2). Only very brief descriptions of these rocks have been published heretofore (Schrader, 1915; Stoyanow, 1949 , p. 30-31), although the rocks are discussed at length in an unpublished thesis by Baker (1961).

The UX Ranch block of volcanic and sedimentary rocks (the UX Ranch is named the Flying $R$ Ranch on the Lochiel quadrangle map) underlies much of the north half of the mapped area in the Patagonia Mountains (fig. 2). To the northeast the UX Ranch block is faulted against Precambrian, Paleozoic, and Mesozoic rocks along the Harshaw Creek fault, on which the stratigraphic separation is at least 2 miles and the apparent left-lateral slip may be as"much as 4 or 5 miles. The northwest boundary of the block is the Bluenose fault, a major structure of undetermined but surely large displacement. At its south end the block is separated from the Duquesne block of silicic volcanic rocks by an upfaulted irregular body of Paleozoic sedimentary rocks that underlie the Washington Camp-Duquesne mining area, between the Kansas and Bonanza faults.

Northeast of the UX Ranch block, and separated from it by the Harshaw Creek fault, are the smaller American Mine and Corral Canyon blocks, mostly of volcanic rocks. These blocks are separated from each other by the American fault, a fault zone poorly defined for most of its length, but along which the stratigraphic separation appears to be at least 4,000 feet. On its south side, the Corral Canyon block is in contact with Paleozoic rocks along the Corral Canyon fault, which has a displacement of at least a few hundred feet, perhaps much more.

Northwest of the UX Ranch block is the Thunder Mine block, composed of highly altered silicic volcanic and plutonic rocks and of some sedimentary rocks. The mutual boundary of the two blocks is the Bluenose fault.

\section{UX RANCH BLOCK}

The southeastern part of the UX Ranch block consists of volcanic rocks-dominantly silicic and alkalic lavas and tuffs-and minor amounts of sandstone, siltstone, and conglomerate. These rocks dip moderately northwest, but reliable attitudes can rarely be measured. The base of this sequence is not exposed, as it is cut out along the Kansas fault, which forms the contact between the volcanics and the Paleozoic rocks of the Washington Camp-Duquesne area; but the thickness northwest of the fault is estimated at 6,000-7,000 feet. The volcanic rocks are overlain disconformably by several thousand feet of fine-grained clastic sedimentary rocks of the Bisbee Formation (Lower Cretaceous).

The volcanic rocks of the UX Ranch block are mostly light-colored-gray to to light-gray, pink, or brownish-gray-fine-grained to sparsely porphyritic lavas and tuffs. In most of the block, tuffs appear to be appreciably more abundant than flows; but in the western and southern parts of the block, metamorphism by Tertiary granodiorite has made it difficult or impossible to distinguish between them. Among 60 rocks studied microscopically, about 30 were identified as tuff or welded tuff and 20 as lavas; the other 10 could not be identified with certainty because of metamorphism.

The lithology of a partial section about half a mile north of the Kansas mine is typical of the bulk of the sequence (fig. 3).

Sandstone and quartz-rich tuffaceous sandstone are interlayered with volcanic rocks throughout the sequence and also form three thick lenses that are shown in figure 2. Sandstones probably comprise less than 5 percent of the sequence. The stubby lens of sandstone 2,000 feet south of the UX Ranch is about 2,000 feet long and has a maximum thickness of about 600 feet; to the northeast it is cut off by the Harshaw Creek fault. The sandstone is a poorly sorted and obscurely bedded pale-red rock which contains a few pebbly layers made up of fragments of volcanic rocks. It consists mainly of subrounded quartz grains in a very fine grained matrix of clay and hydromica (?). Minor components include lithic fragments, iron ore, and blue-gray tourmaline. About 65 percent of the rock is quartz grains, 10 percent is other mineral or rock fragments, and 25 percent is matrix.

The sandstone lenses near the middle and near the head of Finley and Adams Canyon are even-grained quartzitic rocks which are composed of quartz and minor tourmaline, feldspar, and rock fragments, in a sparse mica-rich matrix.

Grayish-red tuffaceous siltstone is a minor rock in the middle and upper parts of the volcanic sequence. It consists largely of very dusty devitrified glass, quartz, and feldspar.

\section{DUQUESNE BLOCK}

The Duquesne block consists largely of light-colored sparsely porphyritic rhyolite that has conspicu- 


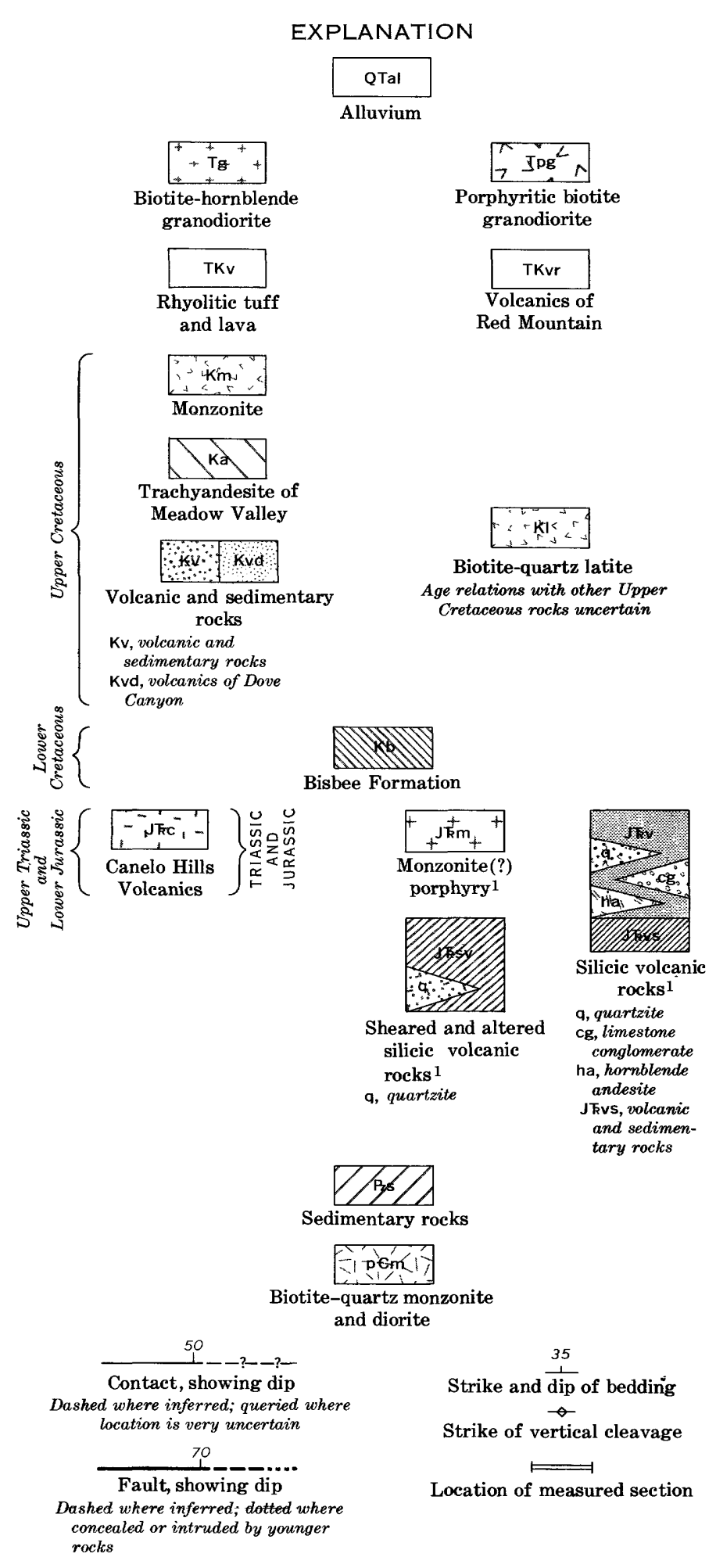

1Age relations between units uncertain.

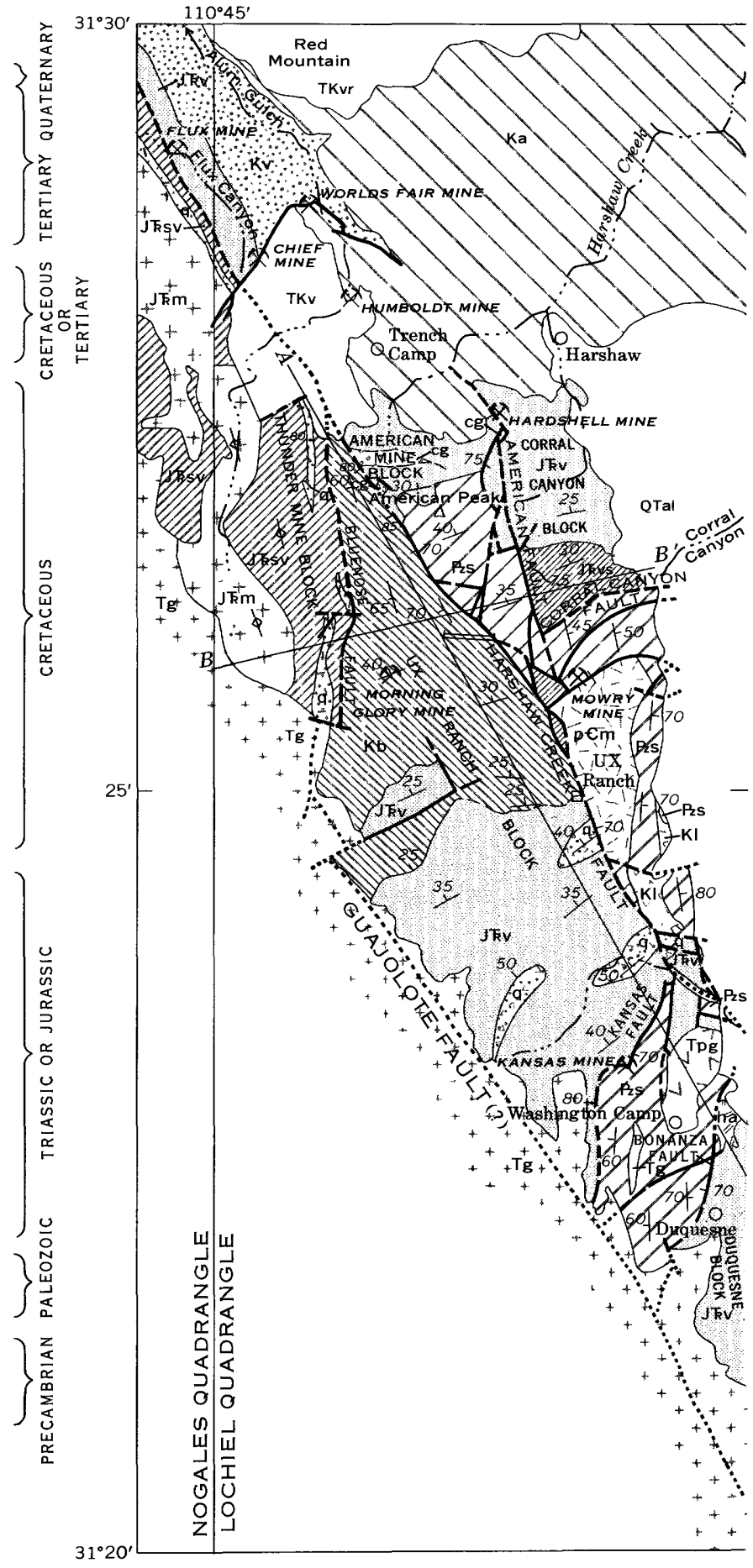



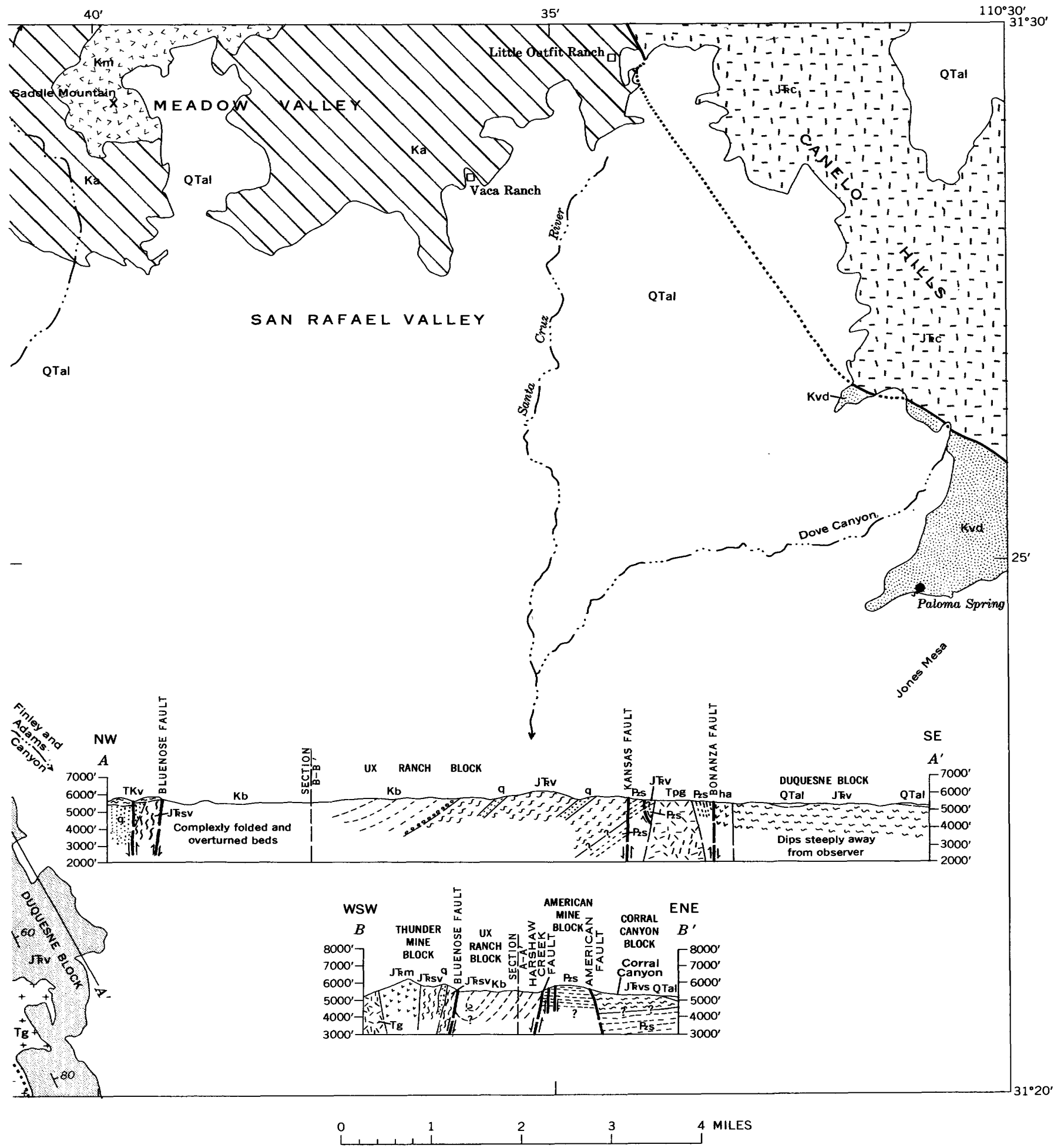

part of the Patagonia Mountains and Canelo Hills. 


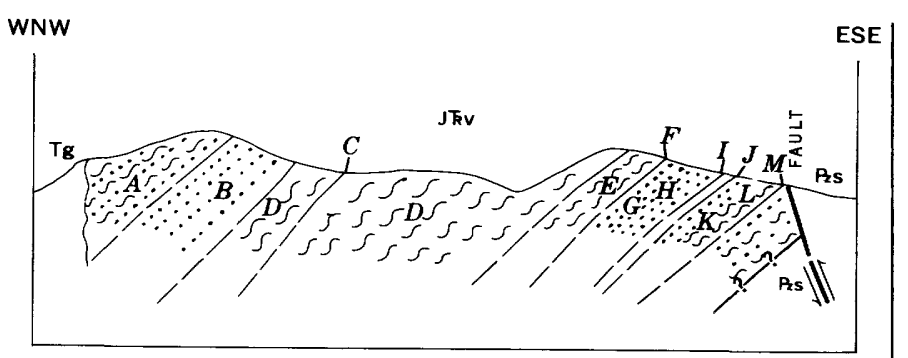

O $\quad 1000 \quad 2000$ FEET

Figure 3.-Partial section of Jurassic or Triassic volcanic and sedimentary rocks of the UX Ranch block north of the Kansas mine. Vertical scale equals horizontal scale. From youngest to oldest:

Tg Tertiary granodiorite.

J Tr v Jurassic or Triassic voleanic and sedimentary rocks of the UX Ranch block:

$A$, Dominantly silicic tuffs; some lavas.

$B$, Yellowish-gray fine-grained sandstone. Mostly interlocked grains of quartz $0.1-0.4 \mathrm{~mm}$ across. Sparse interstitial sericite and potassium

feldspar and a little zircon and iron ore.
$C$, Light-greenish-gray fine-grained porphyritic rhyolite. Phenocrysts $5 \mathrm{~mm}$ a aross of dusty perthitic potassium feldspar and albite. Groundmass is fine-grained mosaic of quartz and potassium feldspar which contains lenses of granular quartz

$D$, Medium-light-gray finely streaked rhyolite (table $1, \mathrm{col}, 10)$. Almost entirely devitrified glass; a little sericite and tourmaline. Quartz entirely devitrified gloss; a little sericite and tousering.
forms lenses along flow layering

$E$, Grayish-purple to dark-gray prominently streaked porphyritic rhyolite (table 1, col. 4). Phenocrysts of sericitized and epidotized antiperthitic albite in a devitrified glassy groundmass. Very sparse
grains of potassium feldspar and pale-green hornblende.

$F$, Light-gray to white lava with prominent flow layering. Phenocrysts of sericitized albite in a dusty groundmass of devitrified glass containing num

$G$, Medium-dark-gray sparsely crystallic quartz latitic(?) welded tuff. Resembles unit $\mathrm{F}$ but has more distinct vitroclastic texture.

$H$, Medium-gray quartz latitic vitric-crystal welded(?) tuff (table 1, col. 1). Sparse fragments of very sodic plagioclase and perthitic potassium feldspar embedded in a vaguely vitroclastic matrix of devitrified pumice and shards. Secondary minerals are abundant pyrite and sericite, and a little tourmaline.

I, Medium-dark-gray coarsely porphyritic hornblende trachyandesite. Phenocrysts $1 \mathrm{~cm}$ long of dusty sericitized oligoclase and smaller crystals of green hornblende in a matrix of oliguclase microlites, hornblende, potassium feldspar, and iron oxides.

$J$, Light-gray very flne grained tuff(?). Small grains of sparse quartz a little sericite, and abundant pyrite in a very dusty matrix of quartz and potassium feldspar.

$K$, Pale-yellow rhyolitic welded tuff ( table 1, col. 6 ). Sparse small grains of sodic plagioclase and quartz in groundmass of devitrified glass showing faint eutaxitic texture. Sparse muscovite and opaque minerals.

$L$, Dark-gray porphyritic latite(?). Phenocrysts 1-2 mm long of very dusty much altered sodic plagioclase in a matrix of devitrified glass.

$M$, Medium-gray poorly sorted sandstone. Interlocked grains of quartz $0.05-0.3 \mathrm{~mm}$ across; some zircon. Interstitial sericite, biotite, clay, Pz s Paleozoic sedimentary rocks.

ous flow layering and streaks and lenses of granular quartz. Spherulitic lavas are common. Tuff and epiclastic volcanic conglomerate are minor components, and the north tip of the block is a small intrusive body of hornblende andesite. Much of the block has been converted to hornfels by Tertiary granodiorite. The scarcity of volcaniclastic or sedimentary interbeds that might aid in determining the attitude of the silicic flows precludes any but a very rough estimate of thickness; the rocks in general appear to dip moderately to steeply eastward, and the thickness may be several thousand feet. Neither the base nor the top of the volcanics is present; to the north the block is delimited by the Bonanza fault and to the west, by granodiorite; to the east it is overlain by alluvium. The rocks closely resemble those of the lower part of the UX Ranch block, the principal difference being the lack of large sandstone bodies in the Duquesne block, and the two sequences almost surely are correlative.

A typical lava in this block is a light- to mediumgray or pale-purple rock with sparse small phenocrysts of antiperthitic albite in a groundmass of glass that has devitrified to patches of fine-grained potassium feldspar and quartz. Abundant lenses of granular quartz with irregular selvages of finegrained potassium feldspar lie parallel to the flow layering. Where converted to hornfels, the lavas have a fine-grained sugary groundmass of quartz, potassium feldspar and a little sericite, epidote, piedmontite, and tourmaline.

The hornblende andesite at the north tip of the Duquesne block is a dark-gray rock which contains abundant millimeter-sized or smaller phenocrysts of andesine set in an intergranular groundmass of andesine microlites, strongly pleochroic blue-green hornblende, and iron ore. Dikes of similar rock cut volcanic rocks in both the Duquesne and UX Ranch blocks but were not seen in any younger rocks; therefore, the hornblende andesite is shown on the geologic map as part of the volcanic sequence of the Duquesne block.

\section{CORRAL GANYON BLOCK}

The Corral Canyon block consists of a variety of volcaniclastic and volcanic rocks. The total thickness of these rocks is unknown inasmuch as the base is not exposed and reliable structural data are few in the upper part of the sequence, but it is probably at least 5,000 feet and may be considerably more. Rocks within the block comprise a lower, dominantly volcaniclastic sequence at least 2,000 feet thick and an upper, dominantly volcanic sequence at least 3,000 feet thick.

\section{VOLCANICLASTIG SEQUENGE}

The volcaniclastic sequence is made up of epiclastic volcanic conglomerate, tuffaceous sandstone and siltstone, and silicic to intermediate tuff, welded tuff, and lava flows. The thickest section of the sequence is along the west side of the block, and the following descriptions apply to that area. Because many units in the sequence are lenticular, the section on the east side of the block differs in many details from that on the west side, but the same rock types are present and therefore will not be further described. The volcaniclastic rocks are similar to those in the upper part of the volcanic sequence of the UX Ranch block; in particular, beds of red tuffaceous siltstone and sandstone are common to both sequences. 
The lowest beds in Corral Canyon are red to gray epiclastic volcanic conglomerate and interbedded red tuffaceous sandstone, pebbly tuff, and silty tuff. Conglomerate forms beds as much as 6 feet thick and consists mainly of rounded to subanglar pebbles and cobbles of silicic volcanic rocks in a grit or sand matrix containing abundant rock fragments. The conglomerate clasts include brown to purple silicic lava, welded tuff, and silty to sandy tuff as well as some limestone, chert, and quartzite. This conglomeratic sequence is several hundred feet thick and is overlain by about 100 feet of crossbedded and channeled maroon tuffaceous siltstone and sandstone containing abundant carbonate grains.

Resting on the maroon beds is about 200 feet of purple or red tuff, tuffaceous sandstone, volcanic pebble conglomerate, and, at the top, about 15 feet of purplish-gray porphyritic andesite(?). Beds of fine-grained and finely laminated maroon tuff $0.5-4$ feet thick are conspicuous. A typical grayish-redpurple feldspathic tuff consists of fragments of altered sodic plagioclase, fragments of mafic minerals completely altered to carbonate and iron oxide, and dark lithic fragments in a very dusty matrix containing much iron oxide.

Overlying the dominantly red basal part of the volcaniclastic unit is a heterogeneous sequence 900 1,000 feet thick that is mostly gray tuff in the lower part and gray to green lava and flow breccia in the upper part. The basal 30 feet or so of the tuffaceous part is a light-greenish-gray massive vitric tuff of latitic or dacitic composition. Locally the tuff is separated from the underlying red rocks by a thin flow of purplish-gray porphyritic andesite. The tuff consists of phenocrysts 1-3 mm (millimeters) across of altered plagioclase, pink sericitized potassium feldspar, biotite largely converted to iron oxide, and a few of quartz, in a matrix of devitrified glass shards. The overlying tuffs are similar but contain more lithic fragments. Near the west end of the outcrop area the tuff contains a thin flow of very fine grained violet silicic lava. The upper part consists mainly of grayish-green to green porphyritic andesitic or trachyandesitic lava and flow breccia with minor moresilicic and conspicuously flow-layered lavas. The andesitic lavas enclose lenses and thin beds of brown slightly feldspathic sandstone. All the andesites are altered; plagioclase is saussuritized, and pyroxene is converted to serpentine minerals.

The upper part of the volcaniclastic sequence is another heterogeneous group of rocks 600-700 feet thick that comprises varicolored silicic welded tuff, tuff, and pebbly tuff, maroon sandstone and siltstone, and red to gray lavas and flow breccias of intermediate and silicic composition. The lowest rock of this group is a light-olive-gray latitic(?) welded tuff as much as 60-70 feet thick that forms a prominent outcrop along the high hill north of Corral Canyon. This tuff is made up of sodic plagioclase phenocrysts, pumice lentils, and a few lithic fragments in a dense matrix of moderately welded and devitrified potassium-rich glass shards. The upper rocks of the group are, from bottom to top, a bed $\mathbf{4 0}$ feet thick of hard maroon sandstone containing sparse flecks of carbonate, grayish-red fine-grained porphyritic andesite, dark-gray very fine grained conspicuously streaked rhyolite or latite, fine-grained platy red vitric rhyolitic tuff, and, at the top, a prominent flow of biotite trachyte (?). The trachyte (?) is a mediumgray porphyry that contains 1- to 2-mm phenocrysts of sodic plagioclase and smaller crystals of highly altered biotite in a very fine grained groundmass of plagioclase microlites and interstitial potassium feldspar and a little quartz.

VOLCANIC SEQUENCE

The volcanic sequence comprises a lower part 650 750 feet thick of intermediate to silicic lavas and an upper part of highly silicic lavas and tuffs of uncertain but appreciable thickness, perhaps 2,000-2,500 feet. Stratigraphic relations between these rocks and those in other structural blocks are not known; some lithologic similarities between lavas in the Corral Canyon and American Mine blocks, however, suggest a possible correlation of at least parts of those blocks.

The lower part of the volcanic sequence consists of conspicuously flow-layered porphyritic andesite or trachyandesite, with some very platy and streaked porphyritic rhyolite or quartz latite toward the base and silicic welded tuff and a little feldspathic sandstone at the top. The andesitic lavas are commonly red or purple and have abundant phenocrysts of sodic plagioclase and much-altered mafic minerals, together with sparse potassium feldspar phenocrysts, in a very fine grained conspicuously flow-layered groundmass. The silicic lavas are gray to reddishpurple very fine grained and finely laminated rocks that contain abundant lenses and streaks of quartz. They contain sparse phenocrysts of sodic plagioclase, potassium feldspar, and highly altered mafic minerals. The quartz lenses are coarsely granular and have selvages of tiny crystals of potassium feldspar. Welded tuff at the top of the lava pile is $\mathbf{4 5 - 5 0}$ feet thick. It is a moderate-red to yellowish-brown rock which contains sparse phenocrysts 1-2 mm 
across of sodic plagioclase, potassium feldspar, biotite, and quartz, and a few lithic fragments in a completely devitrified matrix of shards and pumice.

The upper part of the volcanic sequence is a monotonous pile of silicic lava and flow breccia, tuff, welded tuff, and a few thin beds of quartzite. Lavas appear clearly to predominate over tuffs, although no quantitative estimate of proportions was attempted. The rocks appear in general to dip $25^{\circ}-45^{\circ}$ N., but structural data are so scanty that no accurate estimate of thickness is possible.

The lavas of the upper part are typically light colored, very fine grained, and sparsely porphyritic to nonporphyritic, and they display conspicuous much-contorted flow layering. The groundmass is everywhere devitrified, and many lavas are highly spherulitic; one flow $\mathbf{5 0}$ feet thick consists of about $\mathbf{7 5}$ percent spherulites 1-3 inches in diameter. Another flow contains lithophysae as much as 1 foot across. A typical rhyolite from a locality 1,500 feet southeast of the Hardshell mine consists of phenocrysts as much as $5 \mathrm{~mm}$ across of albite, potassium feldspar, and possibly biotite in a coarsely devitrified groundmass that is mostly potassium feldspar and quartz. A common rock along upper Hermosa Canyon is a pale-brown to pale-red abundantly porphyritic quartz latite or dacite. It contains $1-$ to $2-\mathrm{mm}$ phenocrysts of albite and perthitic potassium feldspar, and a few of cloudy and altered biotite, in a groundmass of glass now devitrified to a fine-grained aggregate of quartz and feldspar.

Welded tuffs occur throughout the upper lava sequence. All appear to be rhyolitic and potassic. Light-gray welded tuff at the Hardshell mine contains phenocrysts of potassium feldspar, and a few of quartz, in a moderately welded coarse matrix of devitrified glass shards and pumice fragments. Another similar welded tuff is underlain by a bed as much as 20 feet thick of quartzite that crops-out for more than 1,500 feet along the strike. The quartzite has about 70 percent subrounded quartz grains 0.1-0.3 $\mathrm{mm}$ in diameter and 30 percent chalcedonic groundmass containing small amounts of feldspar and rock fragments.

A small body of limestone conglomerate is enclosed in volcanics about 1,000 feet south of the Hardshell mine (fig. 2). The conglomerate is $40-45$ feet thick. It consists entirely of jumbled blocks of limestone (most of which appear to be Concha Limestone of Permian age) in various shapes and in sizes as large as 3 feet across.

The stratigraphically highest rocks in the Corral Canyon block, immediately underlying the trachy- andesite of Meadow Valley, consist of purplish-gray rhyolitic flow breccia, gray finely laminated silicic tuff, and some volcanic conglomerate.

\section{AMERICAN MINE BLOCK}

The American Mine block is a faulted wedge of Paleozoic sedimentary rocks and Mesozoic volcanic rocks lying between the UX Ranch block to the west and the Corral Canyon block to the east. The contact between Paleozoic and Mesozoic rocks is very poorly exposed but is interpreted as an unconformity; if such an interpretation is correct this is the only place in the Patagonia Mountains where the contact is not a fault. The volcanic rocks appear to dip moderately northward; but, as in the upper part of the Corral Canyon block, almost nowhere can an attitude be determined with confidence.

The rocks of the American Mine block are silicic lavas and flow breccias with subordinate silicic tuffs and a large lens and several smaller bodies of limestone conglomerate (Simons and others, 1966, p. D17-D19). The volcanic rocks are similar to those of the other Patagonia Mountains blocks, especially the upper part of the Corral Canyon block. Limestone conglomerate is much more abundant than it is in other blocks.

The lavas are varicolored but mainly light gray to pale red. They are porphyritic and nonporphyritic and commonly have conspicuous contorted flow layering and quartzose streaks and lenses. The porphyritic rocks contain $30-40$ percent phenocrysts, most of sodic plagioclase and quartz but some of potassium feldspar and completely altered mafic minerals, in a matrix of feldspar microlites and devitrified glass. The nonporphyritic lavas are made up almost wholly of devitrified, and in some flows, spherulitic, glass that encloses irregular streaks and lenses of quartz, or of quartz with a selvage of tiny potassium feldspar crystals, or of a granular aggregate of the two minerals.

The base of the volcanic rocks at the east edge of the block is marked locally by silicified rock that could possibly indicate a fault or a fault zone. The lowest volcanic rocks are a sequence of light-colored hard well-bedded fine-grained vitric tuff and sandy tuff about 50 feet thick. These rocks are about parallel to the underlying Paleozoic limestone. A typical tuff here consists almost entirely of devitrified glass shards and dust and includes a few small quartz grains.

Rocks in the uppermost part of the block, immediately beneath the trachyandesite of Meadow Valley, are light-gray to reddish-purple porphyritic flow breccias and lavas that are conspicuously flow 
layered. Phenocrysts are albite and completely altered mafic minerals, and the groundmass is devitrified glass. Just southwest of the Hardshell mine the stratigraphically highest rock is a light-gray welded tuff. It consists of millimeter-sized phenocrysts of potassium feldspar and sparse quartz, and lithic fragments, in a matrix of glass shards whose texture has been almost completely obliterated by devitrification.

The large lens of limestone conglomerate near the north end of the block (fig. 2) is a chaotic aggregate of irregular subangular to angular blocks, primarily of brecciated limestone but including many of quartzite and some of dolomite and silty or sandy limestone, in a sparse matrix of silicic volcanic debris. The maximum thickness is estimated to be several hundred feet, but it is very uncertain because exposures are poor. Eastward the conglomerate thins abruptly and pinches out about 3,500 feet east of Harshaw Creek; to the west it is cut off by the Harshaw Creek fault (Simons and others, 1966, p. D18, fig. 4A). Conglomerate clasts generally range in size from sand to blocks 5 feet or more across, and one block is $\mathbf{1 0 0}$ feet or more across. Most blocks have been pervasively shattered into fragments less than an inch across and then healed. The clasts are mainly Concha Limestone (Permian) ; the quartzite is probably from the Scherrer Formation, and the dolomite and impure limestone may be from the Epitaph Dolomite, both also of Permian age. Locally the base of the conglomerate contains much angular volcanic debris, some fragments of which are as much as 1 foot across. The conglomerate lens is as much as 1,000 feet stratigraphically above the base of the volcanics, and the nearest outcrops of possible source rocks are about 1,000 feet south.

\section{THUNDER MINE BLOGK}

The Thunder Mine block is the most northwestern of the Patagonia Mountains Mesozoic blocks. It is bounded on the east by the Bluenose and Harshaw Creek faults and on the west by plutons of Tertiary and Jurassic age. The block is composed of sheared and much-altered silicic volcanic rocks, some quartzite, and highly altered monzonite and other intrusive igneous rocks. No direct evidence of the age of the volcanic and sedimentary rocks is available; but they are surely of Mesozoic age, and their considerable degree of alteration and deformation suggests an early Mesozoic age.

The thickness of the volcanic-sedimentary sequence in the Thunder Mine block is very uncertain. Almost no reliable data on the attitude of the rocks could be obtained, and the combination of shearing and alteration makes it difficult, and in places impossible, to distinguish between extrusive and intrusive igneous rocks. The general impression is of north-northwesterly strike and steep dips, and it seems likely that at least 1,000 feet, and perhaps 2,000 or even 2,500 feet, of mixed volcanic and sedimentary rocks is present.

The rocks of the Thunder Mine block are mainly light-colored-light-gray to grayish-red, pale-red, and lavender-porphyritic to aphanitic silicic lavas, flow breccias, and tuffs with intercalated fine- to medium-grained quartzose sedimentary rocks. Porphyritic lavas have phenocrysts 1-5 $\mathrm{mm}$ long of sodic plagioclase (commonly nearly pure albite), and a few of quartz, embedded in a fine-grained quartz-feldspar aggregate that probably is devitrified glass. Flow (?) breccia near the Sunnyside mine is a light-gray to lavender rock consisting of abundant angular fragments of volcanic rock mostly less than 2 inches across in a fine-grained matrix of porphyritic rhyolite. Many rocks identified as volcanic in the field proved upon microscopic examination to be so completely converted to various combinations of quartz, sericite, alunite, and kaolinite that their original nature could not be determined; presumably, some of these were originally fine-grained silicic and glassy volcanics.

Sedimentary rocks interbedded with the volcanics are also altered but have retained more of their original features. They include nearly pure quartz sandstone and silty or tuffaceous sandstone. A bed of quartzite that forms a prominent rib along the east side of the block (fig. 2) ranges from a few feet to at least 100 feet in thickness. It is a light-gray to pale-red rock made up of partly rounded and somewhat interlocked or sutured grains of quartz 0.05$0.5 \mathrm{~mm}$ across and sparse interstitial sericite. Quartz grains 1-2 $\mathrm{mm}$ in diameter are scattered through the finer grained material. Very sparse zircon and feldspar are the only other detrital minerals in the rock. Locally the quartzite has some thin beds of pebble conglomerate or breccia, and siltsone. Near the Flux mine (fig. 2), the quartzite is brecciated and silicified.

Silty sandstones consist of angular to subrounded quartz grains in an abundant silty or muddy matrix now altered to sericite. In some rocks the matrix is a fine-grained quartz-sericite-iron oxide aggregate, possibly altered tuffaceous material. As in the sandstones, the only detrital minerals are quartz and very sparse zircon and feldspar.

\section{CHEMICAI. COMPOSITION}

Chemical analyses, norms, and semiquantitative 
spectrographic analyses of nine volcanic rocks from the UX Ranch and Duquesne blocks are given in table 1. Also tabulated for comparison are analyses and norms of rhyolite and rhyolitic welded tuff from the Canelo Hills Volcanics, two Jurassic granites from the Patagonia Mountains, and Nockolds' (1954) average alkali rhyolite and average dellenite [= quartz latite $]$.

The rocks from the UX Ranch and Duquesne blocks are, with one exception, rhyolites with high alkali contents (8-9.5 percent), high to very high ratios of $\mathrm{K}_{2} \mathrm{O}$ to $\mathrm{Na}_{2} \mathrm{O}$ (1.3:1 to $3.1: 1$; in one rock the ratio is less than $1: 1)$, and very low $\mathrm{CaO}(<0.5$ percent) ; they correspond closely to average alkali rhyolite of Nockolds (1954, p. 1012). The exception, a quartz latitic welded(?) tuff, has 1.3 percent $\mathrm{CaO}$ and somewhat less $\mathrm{SiO}_{2}$ than the rhyolites but is otherwise similar. Rhyolites from the Canelo Hills Volcanics are more silicic and show extremely high ratios of $\mathrm{K}_{2} \mathrm{O}$ to $\mathrm{Na}_{2} \mathrm{O}$ (8:1 and $43: 1$ ). Alkali.granite that underlies much of the west-central part of the Patagonia Mountains (not shown in fig. 2) and intrudes silicic volcanic rocks of the Thunder Mine block is chemically almost identical with the rhyolites in both major and trace element composition; the similarity is evident in the individual analyses and is particularly striking in averages of chemical analyses of the eight alkali rhyolites and the two granites of table 1 , as shown in table 2.

Consanguinity of the rhyolites and granites suggested by the chemical analyses is supported by similarities in probable ages. Geologic evidence suggests that the volcanics are Triassic or Jurassic in age, and zircon from the analyzed granite of table 1 , column 14, has been dated by the lead-alpha method at $160 \pm 20$ m.y., or Jurassic (T. W. Stern, written commun., 1965). Evidence is accumulating from the Patagonia Mountains as well as elsewhere in southern Arizona that the time interval within 10-20 m.y. of the Triassic-Jurassic boundary (about 190-195 m.y.) was a period of widespread alkalic magmatism.

\section{AGE AND GORRELATION}

The assignment of the silicic volcanic rocks of the southern Patagonia Mountains to the Triassic or Jurassic is based on geologic relations within and among the several structural blocks, on radiometric dating of a granite that intrudes the volcanic rocks, and on correlation with lithologically similar rocks in nearby areas that have been dated by various radiometric methods. No identifiable indigenous fossils have been found in any of the volcanics and probably none will be found, as the rocks are mostly welded tuff or lava and thus were unfavorable for the incorporation or preservation of fossils.

The volcanic rocks of the American Mine block rest unconformably on Concha Limestone and Scherrer Formation of Early Permian age and contain conglomerate with clasts of undoubted Concha Limestone; the volcanics in this block are therefore no older than Early Permian. Similar volcanic rocks in the UX Ranch block are overlain disconformably by the Bisbee Formation of Early Cretaceous age and therefore are no younger than Early Cretaceous. No other evidence on the age of the volcanics based on paleontologically dated rocks is available. Rocks of both the American Mine and the Corral Canyon blocks are overlain unconformably by the trachyandesite of Meadow Valley, which has been dated radiometrically as Late Cretaceous (p. E21).

Volcanic rocks of the Thunder Mine block are intruded by a granite that is believed to be the same as a granite in Comoro Canyon on the west-central slope of the Patagonia Mountains. The granite of Comoro Canyon has been dated as Jurassic (160 \pm 20 m.y.) by the lead-alpha method on zircon. Although the two granites are separated by a screen a mile or so wide of plutonic and metavolcanic rocks, they are correlated with considerable confidence on the basis of similar geologic relations and chemistry (table 1, cols. 14 and 15). It seems likely, therefore, that the volcanics are no younger than Jurassic. The rocks are lithologically similar to those of the Mount Wrightson Formation of Triassic age in the Santa Rita Mountains (Drewes, 1968, p. C6-C7), and, as noted previously, their considerable degree of deformation and alteration also suggests an early Mesozoic age.

The volcanic rocks of UX Ranch block, especially the lower 5,000 feet or so, and those of the Duquesne block are lithologically and chemically very similar to those of both the Mount Wrightson Formation and the Canelo Hills Volcanics. In particular, they resemble the middle member of the Mount Wrightson, which is dominantly rhyolitic and latitic lava, welded tuff, and breccia enclosing lenses of sandstone and quartzite, and a few of conglomerate.

The volcaniclastic sequence of the Corral Canyon block resembles both the Gardner Canyon Formation and the lower member of the Canelo Hills Volcanics in containing epiclastic volcanic conglomerate, red siltstone, sandstone and tuffaceous sedimentary rocks and silicic lava and tuff. Although no thin beds of limestone such as those in the Gardner Canyon Formation were found, some of the red siltstones have carbonate-rich layers, and other sedimentary 
TABLE 1.-Comparison of chemical analyses, norms, and semiquantitative spectrographic analyses of Mesozoic volcanic rocks, Patagonia Mountains, with those of associated igneous and Nockolds' (1954) average rocks

[Leaders (--) in figure columns indicate no data]

\begin{tabular}{|c|c|c|c|c|c|c|c|c|c|c|c|c|c|c|c|}
\hline \multirow[b]{3}{*}{$\begin{array}{l}\text { Sample No } \\
\text { Lab. No }\end{array}$} & \multicolumn{2}{|c|}{ Quartz latite } & \multicolumn{11}{|c|}{ Alkali rhyolite and rhyolitic tuff } & \multicolumn{2}{|c|}{ Granite } \\
\hline & Pata- & $\begin{array}{l}\text { Nock- } \\
\text { olds' }\end{array}$ & & & & tagonia & Mountair & & & & $\begin{array}{l}\text { Nock- } \\
\text { olds' }\end{array}$ & Canel & Hills & Comoro & Flux \\
\hline & $\stackrel{1}{163091}$ & 2 & $\begin{array}{c}3 \\
163089\end{array}$ & $\stackrel{4}{163092}$ & $\stackrel{5}{163090}$ & $\begin{array}{c}6 \\
163094\end{array}$ & $\begin{array}{c}7 \\
165055\end{array}$ & $\begin{array}{c}8 \\
165053\end{array}$ & $\begin{array}{c}9 \\
165054\end{array}$ & $\begin{array}{c}10 \\
163093\end{array}$ & 11 & $\begin{array}{c}12 \\
159243\end{array}$ & $\begin{array}{c}13 \\
163553\end{array}$ & $\begin{array}{c}14 \\
163087\end{array}$ & $\begin{array}{c}15 \\
160480\end{array}$ \\
\hline
\end{tabular}

(Analysts: Nos. 1, 3, 4, 5, 6, 10, 14, 15, by P. L. D. Elmore, S. D. Botts, G. W. Chloe, Lowell Artis, and H. Smith; 7, 8, 9, 13, by P. L. D.

\begin{tabular}{|c|c|c|c|c|c|c|c|c|c|c|c|c|c|c|c|}
\hline 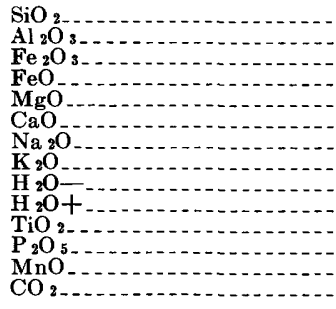 & $\begin{array}{l}66.7 \\
15.9 \\
2.8 \\
1.3 \\
.90 \\
1.3 \\
3.0 \\
6.1 \\
.26 \\
.74 \\
.67 \\
.18 \\
.05 \\
<.05\end{array}$ & $\begin{array}{r}70.15 \\
14.41 \\
1.68 \\
1.55 \\
.63 \\
2.15 \\
3.65 \\
4.50 \\
.68 \\
7.42 \\
.12 \\
\\
\end{array}$ & $\begin{array}{l}70.0 \\
15.4 \\
1.9 \\
.62 \\
1.1 \\
.31 \\
3.9 \\
5.0 \\
.12 \\
.85 \\
.53 \\
.05 \\
.12 \\
<.05\end{array}$ & $\begin{array}{c}71.4 \\
14.8 \\
1.8 \\
.22 \\
.50 \\
.44 \\
3.3 \\
6.2 \\
.15 \\
.60 \\
.39 \\
.05 \\
.05 \\
<.05\end{array}$ & $\begin{array}{c}72.4 \\
14.0 \\
2.7 \\
.20 \\
.10 \\
.28 \\
4.0 \\
5.4 \\
.08 \\
.37 \\
.41 \\
.09 \\
.06 \\
<.05\end{array}$ & $\begin{array}{l}74.0 \\
13.9 \\
2.1 \\
.10 \\
.15 \\
.38 \\
4.6 \\
3.4 \\
.12 \\
.71 \\
.42 \\
.03 \\
.01 \\
<.05\end{array}$ & $\begin{array}{l}75.4 \\
12.8 \\
1.4 \\
.10 \\
.2 \\
.47 \\
2.8 \\
5.2 \\
.17 \\
.63 \\
.20 \\
.00 \\
.04 \\
.22\end{array}$ & $\begin{array}{c}75.6 \\
12.5 \\
1.2 \\
.12 \\
.1 \\
.16 \\
2.2 \\
6.8 \\
.19 \\
.53 \\
.17 \\
.00 \\
.02 \\
<.05\end{array}$ & $\begin{array}{c}75.8 \\
12.4 \\
1.1 \\
.26 \\
.1 \\
.23 \\
2.7 \\
6.0 \\
.20 \\
.45 \\
.18 \\
.02 \\
.03 \\
.11\end{array}$ & $\begin{array}{c}76.1 \\
12.6 \\
.79 \\
.16 \\
.52 \\
.21 \\
2.2 \\
6.2 \\
.36 \\
.74 \\
.11 \\
.00 \\
.02 \\
<.05\end{array}$ & $\begin{array}{r}74.57 \\
12.58 \\
1.30 \\
1.02 \\
.11 \\
.61 \\
4.13 \\
4.73 \\
.66 \\
.17 \\
.07 \\
.05 \\
\end{array}$ & $\begin{array}{c}78.1 \\
11.0 \\
.75 \\
.08 \\
.2 \\
.07 \\
.92 \\
7.4 \\
.19 \\
1.0 \\
.15 \\
0 \\
.04 \\
<.05\end{array}$ & $\begin{array}{c}79.7 \\
10.0 \\
.96 \\
.04 \\
.48 \\
.18 \\
.13 \\
5.6 \\
.69 \\
1.3 \\
.17 \\
.51 \\
.09 \\
<.05\end{array}$ & $\begin{array}{c}73.6 \\
13.4 \\
1.0 \\
.40 \\
.15 \\
.53 \\
3.3 \\
6.1 \\
.19 \\
.53 \\
.22 \\
.00 \\
.04 \\
<.05\end{array}$ & $\begin{array}{c}75.9 \\
12.8 \\
1.0 \\
.15 \\
.07 \\
.03 \\
3.1 \\
5.6 \\
.28 \\
.74 \\
.20 \\
.00 \\
.02 \\
<.05\end{array}$ \\
\hline Sum & 100 & $-\cdots$ & 100 & 100 & 100 & 100 & 100 & 100 & 100 & 100 & $\ldots$ & 99.9 & 100 & 100 & 100 \\
\hline \multicolumn{16}{|c|}{ Norms (percent) } \\
\hline $\begin{array}{l}\text { Q } \\
\text { or } \\
\text { ab } \\
\text { an }\end{array}$ & $\begin{array}{r}22.3 \\
36.0 \\
25.4 \\
5.3 \\
2.4\end{array}$ & $\begin{array}{r}26.1 \\
26.7 \\
30.9 \\
9.5 \\
-9-\end{array}$ & $\begin{array}{r}26.0 \\
29.5 \\
33.0 \\
1.2 \\
3.1\end{array}$ & $\begin{array}{r}27.0 \\
36.6 \\
27.9 \\
1.9 \\
2.0\end{array}$ & $\begin{array}{r}28.0 \\
31.9 \\
33.8 \\
.8 \\
1.3\end{array}$ & $\begin{array}{r}33.3 \\
20.1 \\
38.9 \\
1.7 \\
2.0\end{array}$ & $\begin{array}{r}38.8 \\
30.6 \\
23.6 \\
1.1 \\
2.1\end{array}$ & $\begin{array}{r}36.6 \\
40.1 \\
18.3 \\
1.1 \\
1.2\end{array}$ & $\begin{array}{l}36.4 \\
35.6 \\
23.1 \\
.56 \\
1.2\end{array}$ & $\begin{array}{r}38.4 \\
36.6 \\
18.6 \\
1.0 \\
1.9\end{array}$ & $\begin{array}{r}31.1 \\
27.8 \\
35.1 \\
2.0\end{array}$ & $\begin{array}{l}44.0 \\
43.7 \\
7.8 \\
.35 \\
1.4\end{array}$ & $\begin{array}{r}56.8 \\
33.4 \\
1.1 \\
3.7\end{array}$ & $\begin{array}{r}29.7 \\
36.0 \\
27.9 \\
2.6 \\
.41\end{array}$ & $\begin{array}{l}36.3 \\
33.1 \\
26.2 \\
.15 \\
1.6\end{array}$ \\
\hline & 2.2 & $\begin{array}{r}.2 \\
1.6 \\
8\end{array}$ & 2.7 & 1.2 & .25 & .37 & .50 & .20 & .20 & 1.3 & $\begin{array}{l}.1 \\
.3 \\
6\end{array}$ & .50 & 1.2 & .37 & .17 \\
\hline $\begin{array}{l}\mathrm{hm}_{-} \\
\text {il_-- } \\
\text { ap.- }\end{array}$ & $\begin{array}{l}2.4 \\
1.1 \\
1.3 \\
.43\end{array}$ & $\begin{array}{l}.0 .5 \\
.8 \\
.3\end{array}$ & $\begin{array}{l}.85 \\
1.3 \\
1.0 \\
.12\end{array}$ & $\begin{array}{c}1.8 \\
.57 \\
.12\end{array}$ & $\begin{array}{r}2.7 \\
.55 \\
.21\end{array}$ & $\begin{array}{c}2.1 \\
.23 \\
.07\end{array}$ & $\begin{array}{l}1.4 \\
.15\end{array}$ & $\begin{array}{l}1.3 \\
.15\end{array}$ & $\begin{array}{l}.23 \\
.96 \\
.46\end{array}$ & $\begin{array}{l}.26 \\
.61 \\
.21\end{array}$ & $\begin{array}{l}.0 \\
.3 \\
.2\end{array}$ & $\begin{array}{l}.75 \\
.26\end{array}$ & $\begin{array}{r}.96 \\
.15 \\
1.3\end{array}$ & $\begin{array}{l}.78 \\
.46 \\
.42\end{array}$ & $\begin{array}{l}1.0 \\
.36\end{array}$ \\
\hline & 83.7 & 83.7 & 88.6 & $91^{.09}$ & $93.7^{.12}$ & $9 .^{.30}$ & 93.0 & 95.0 & 95.1 & 93.6 & 94.0 & 95.5 & 91.36 & $93.7^{-}$ & 95.01 \\
\hline
\end{tabular}

Semiquantitative spectrographic analyses (parts per million)
(Analysts: Nos. 1, 3, 4, 5, 6, 10, 14, by Barbara Tobin and J. C. Hamil ton; 7, 8, 9, by W. B. Crandell; 12, M. Conklin; 15, by J. C. Hamilton. 0, looked for but not detected. Looked for but not found: Ag, As, Au, Bi, Cd, Co, Eu, Ge, Hf, Hg, In, Li, Mo, Ni, Pd, Pr, Pt, Re, Sb, $\mathrm{Sm}, \mathrm{Sn}, \mathrm{Ta}, \mathrm{Te}, \mathrm{Tb}, \mathrm{Tl}, \mathrm{U}, \mathrm{W}, \mathrm{Z}_{\mathrm{n}}$.)

\begin{tabular}{|c|c|c|c|c|c|c|c|c|c|c|c|c|c|c|c|}
\hline$a_{-}$ & $\begin{array}{l}0.015 \\
.15 \\
.0002 \\
0 \\
.0001 \\
.0005 \\
.003 \\
.005 \\
0 \\
0 \\
.003 \\
.0015 \\
.03 \\
.002 \\
.005 \\
.0005 \\
.03\end{array}$ & - & $\begin{array}{l}0 \\
.2 \\
.0002 \\
0 \\
.00015 \\
.00015 \\
.005 \\
.005 \\
.0015 \\
0.005 \\
.001 \\
.03 \\
.0015 \\
.005 \\
.0005 \\
.03\end{array}$ & $\begin{array}{l}0 \\
.07 \\
.0003 \\
0 \\
0 \\
.00015 \\
.003 \\
.005 \\
.0015 \\
0.005 \\
.001 \\
.015 \\
0.003 \\
.0005 \\
.015\end{array}$ & $\begin{array}{l}0 \\
. .15 \\
0 \\
0 \\
.0005 \\
.015 \\
.0015 \\
.005 \\
0 \\
0 \\
.003 \\
.001 \\
.015 \\
.0015 \\
.005 \\
.0005 \\
.03\end{array}$ & $\begin{array}{l}0.005 \\
.05 \\
0 \\
0 \\
.00015 \\
.007 \\
.0015 \\
.003 \\
0 \\
0 \\
.0015 \\
.0005 \\
.007 \\
0.002 \\
.0002 \\
.02\end{array}$ & $\begin{array}{l}0 \\
.03 \\
.0001 \\
.01 \\
0 \\
.0001 \\
.001 \\
.007 \\
.001 \\
0 \\
.001 \\
.0005 \\
.005 \\
.0007 \\
.003 \\
.0003 \\
.02\end{array}$ & $\begin{array}{l}0.003 \\
.03 \\
.0002 \\
.01 \\
0 \\
.0003 \\
.001 \\
.005 \\
.001 \\
0 \quad .005 \\
.0005 \\
.007 \\
.0005 \\
.003 \\
.0003 \\
.02\end{array}$ & $\begin{array}{l}0 \\
.03 \\
.0002 \\
.01 \\
0 \\
.0002 \\
.001 \\
.007 \\
.001 \\
0 \\
.0015 \\
.0005 \\
.007 \\
.0003 \\
.003 \\
.0003 \\
.02\end{array}$ & $\begin{array}{l}.015 \\
0 \\
0 \\
.0002 \\
.0005 \\
.002 \\
0 \\
0 \\
0 \\
.002 \\
.0007 \\
.01 \\
0 \\
.003 \\
.0005 \\
.015\end{array}$ & 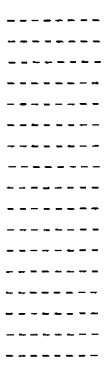 & $\begin{array}{l}0 \\
.03 \\
.0003 \\
0 \\
.0003 \\
.0007 \\
.002 \\
0.002 \\
.007 \\
.003 \\
.002 \\
.1 \\
.02 \\
.005 \\
.0005 \\
.03\end{array}$ & - & $\begin{array}{l}0 \\
0.05 \\
.015 \\
.0002 \\
.0005 \\
.003 \\
.01 \\
0.007 \\
.007 \\
.002 \\
.0007 \\
.01 \\
.0015 \\
.005 \\
.0005 \\
.015\end{array}$ & 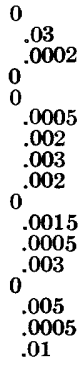 \\
\hline
\end{tabular}

1Differentiation index.

1. Quartz latitic welded(?) tuff, 1,200 ft north of Kansas mine. Sparse fracrMEN DESCRIPTIONS

(Nockolds 1954 p. 1014 plagioclase and potassium feldspar in matrix of devitrified pumice and glass shards.

3. Alkali rhyolitic tuff(?), 1.5 miles west of UX Ranch. Sparse phenocrysts of sodic plagioclase, potassium feldspar, and quartz in hornfel
feldspar, chlorite, and muscovite.
4. Alkali rhyolite, $1,600 \mathrm{ft}$ northwest of Kansas mine. Phenocrysts of altered antiperthitic sodic plagioclase in matrix of devitrified glass.

4. Alkali rhyolite, $1,600 \mathrm{ft}$ northwest of Kansas mine. Phenocrysts of altered antiperthitic sodic plagioclase in matrix of devitrified glass.
5 . Alkali rhyolite, 1 mile south-southeast of UX Ranch. Abundant phenocrysts and crystal fragments of albite in groundmass of small densely packed spherulites.

6. Alkali rhyolitic welded tuff, roadcut $600 \mathrm{ft}$ northwest of Kansas mine. Sparse grains of sodic plagioclase and quartz in matrix of devitrified glass shards.

7. Alkali rhyolite, 1 mile southeast of Duquesne. Sparse phenocrysts of sodic plagioclase in streaked-appearing groundmass of devitrified glass.

8. Alkali rhyolite, 1 mile southeast of Duquesne. Sparse phenocrysts of antiperthitic sodic plagioclase in matrix of coarsely devitrified glass enclosing lenses of coarsely granular aggregates of quartz and potassium feldspar.

9. Alkali rhyolite, 0.9 mile southeast of Duquesne. Sparse phenocrysts of perthite in streaked-appearing matrix of devitrified glass.
10. Alkali rhyolite, 1,800 ft northwest of Kansas mine. Almost entirely devitrified glass enclosing streaks of granular quartz. Traces of sericite and tourmaline.

12. Alkal rhyolitic welded tuff, Canelo Hills Volcanics. Biotite from this rock has been dated by the potassium-argon method at $173 \pm 7$ m.y. (Hayes and others, 1965 , 12. Al. M6-M7).

14. Granite of Comoro Canyon, west-central Patagonia Mountains, Nogales quadrangle. Zircon from this rock has been dated by the lead-alpha method at $160 \pm 20$

15. Granite of Flux Canyon, northwest flank of Patagonia Mountains, Nogales quadrangle. 
TABLE 2.-Average chemical analysis of rhyolites and granites, Patagonia Mountains

[Results in percent]

\begin{tabular}{|c|c|c|}
\hline & $\begin{array}{c}\text { Average of } 8 \\
\text { alkali rhyolites }\end{array}$ & $\begin{array}{c}\text { Average of } 2 \\
\text { alkali granites }\end{array}$ \\
\hline 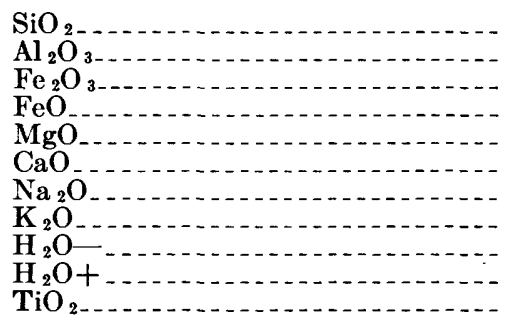 & $\begin{array}{l}73.8 \\
13.5 \\
1.6 \\
.22 \\
.34 \\
.31 \\
3.2 \\
5.5 \\
.17 \\
.61 \\
.30\end{array}$ & $\begin{array}{l}74.7 \\
13.1 \\
1.0 \\
.27 \\
.11 \\
.28 \\
3.2 \\
5.8 \\
.23 \\
.63 \\
.21\end{array}$ \\
\hline $\begin{array}{l}\text { Sum, not including very small } \\
\text { amounts of } \mathrm{P}_{2} \mathrm{O}_{5}, \mathrm{MnO} \text {, and } \\
\mathrm{CO}_{2}\end{array}$ & 99.55 & 99.53 \\
\hline
\end{tabular}

or tuffaceous sedimentary rocks contain abundant irregularly dispersed carbonate, some of which may be redistributed primary material. As stated previously (p. E4), the lower members of the Canelo Hills Volcanics was correlated by Hayes $(1970$ a, p. A8A9) with the Gardner Canyon Formation.

In summary, then, the silicic volcanic rocks in the American Mine, Corral Canyon, Duquesne, Thunder Mine, and UX Ranch blocks of the southern Patagonia Mountains constitute sequences that probably are correlative in part with the Mount Wrightson and Gardner Canyon Formations (Triassic) of the Santa Rita Mountains and the Canelo Hills Volcanics (Late Triassic and Early Jurassic) of the Canelo Hills. Some of the silicic volcanics may be youngerLate Jurassic or early Early Cretaceous-but none is known to be younger than the Bisbee Formation of late Early Cretaceous age.

\section{VOLCANIC AND SEDIMENTARY ROCKS IN THE.} FLUX MINE AREA

A small north-northwesterly trending body of volcanic and sedimentary rocks probably of Triassic or Jurassic age is centered roughly on the Flux mine (fig. 2). The outcrop area is about 2.5 miles long and less than 2,000 feet wide. To the west these rocks are in contact along an inferred extension of the Harshaw Creek fault with rocks of the Thunder Mine block. To the east they are probably overlain unconformably by volcanic rocks of presumed Cretaceous age; the nature and location of this contact, however, is very uncertain. In most places the attitude of the rocks is unclear, but in the northern part of the outcrop area, sedimentary beds dip moderately west; consideration of regional geologic relations suggests that these beds are overturned.

The rocks are predominantly light-colored silicic tuff breccia and tuff, welded tuff, and minor lava flows. Sedimentary rocks, which are mainly in the western (lower?) part of the section, consist of coarse- to fine-grained quartzite, sandstone, arkose and shale. A large block of Paleozoic limestone at the Flux mine, and other large blocks or accumulations of blocks of fossiliferous Paleozoic limestone south of the mine, probably were emplaced in the volcanic sequence by landsliding.

Rock along much of Flux Canyon south of the Flux mine is a green silicified tuff breccia composed of angular to rounded clasts of volcanic rocks, and a few of limestone, in a dense tuffaceous or gritty matrix. Breccia fragments are as large as 3 feet across, but most are smaller than 2 inches. Volcanic clasts are gray, purple, or red fine-grained to porphyritic lavas which show conspicuous flow layering. Interlayered with the breccia is some dark-greenishgray fine-grained porphyritic latite (?). All the phenocrystic minerals-plagioclase, biotite, and pyroxene (?) - are much altered, and the glassy flow-layered groundmass is completely devitrified.

Tuff breccias elsewhere in the Flux mine area are finer grained but have abundant rock fragments (mainly silicic volcanics) and variable amounts of feldspar and quartz grains in a devitrified matrix of glass shards that has a well-preserved vitroclastic texture. A welded tuff breccia 1,200 feet north of the Chief mine has conspicuous secondary flowage structures that resemble those of silicic lavas; abundant phenocrysts of potassium feldspar, and a few of quartz and biotite, are embedded in a devitrified matrix of compressed and bent shards and pumice fragments.

Gray, green, and brown shale and some sandstone exposed northwest of the Flux mine are the westernmost rocks of the sequence. Thickness ranges from a few feet to somewhat less than 200 feet. These beds are much faulted and folded, and the rocks weather to small chips. A typical sandstone is made up of about 40 percent angular feldspar grains 0.1$0.3 \mathrm{~mm}$ across, 10 percent quartz, 10 percent veinlets and patches of epidote and carbonate, and 40 percent fine-grained micaceous matrix.

The limestone block at the Flux mine is a lens about 1,000 feet long and as much as 75 feet thick (Simons and others, 1966, p. D18-D19, fig. 4B). The rock is a thoroughly brecciated and healed obscurely bedded gray to dark-gray somewhat cherty limestone with subordinate light-gray dolomitic limestone. The 
lens dips steeply west and is overlain by several tens of feet of grit and sandstone and underlain by a highly altered green diabasic rock and pebbly volcanic sandstone containing sparse fragments of limestone. To the south the limestone block passes into a thin lens of limestone conglomerate. The rocks to the west are made up of coarse arkose, fine-grained sericitic sandstone, and quartzite, all replaced by variable amounts of epidote and tourmaline. No fossils were found in the limestone, so its age is not definitely known but is surely Paleozoic; possibly the limestone is Concha or Colina Limestone (Permian) or, less likely, Escabrosa Limestone (Mississippian).

Another body of limestone, a lens-shaped jumble of large blocks rather than a single block, is 1,000 feet northwest of the Chief mine. It is 500-600 feet long and as much as 100 feet wide, and it consists of fossiliferous limestone and silty and sandy limestone, either Horquilla Limestone (Pennsylvanian) or Earp Formation (Pennsylvanian and Permian). Another lens of fossiliferous cherty limestone 700 feet farther northwest is about $\mathbf{3 0 0}$ feet long and is probably Horquilla Limestone. These limestone bodies are entirely enclosed in volcanic rocks containing a little interbedded sandstone and shale.

\section{CRETACEOUS ROCKS}

Cretaceous sedimentary rocks were first recognized among Mesozoic rocks in the Patagonia Mountains by Schrader $(1915$, p. 53-54) during a reconnaissance study of the Santa Rita and Patagonia Mountains. Fossils found near the Mowry mine were assigned by T. W. Stanton (in Schrader, 1915, p. 53) to the Comanche Series of the Cretaceous. Schrader recognized the possibility that some of the rocks he referred to the Mesozoic might be of preCretaceous age, as has since proved to be true.

Apparently no further work on these rocks was published until Stoyanow (1937) described briefly a Cretaceous sequence in the Patagonia Mountains and named the Patagonia Group, the upper part of which he designated the Molly Gibson Formation. The rocks and their ammonite fauna were described in more detail by Stoyanow in 1949 (p. 30-31, 4041, 53, 128-129). He believed that the Molly Gibson is of latest Early Cretaceous (latest Washita) age and $(1949$, p. 31, 41) that the Patagonia Group might be equivalent to the entixe Fredericksburg and Washita Groups (late Early Cretaceous). The Washita Group is now considered to be of Early and Late Cretaceous age (Imlay, 1944).

Stoyanow's descriptions of the Patagonia Group and Molly Gibson Formation and his age assignments are unsatisfactory because (1) the lithology as given in his 1949 paper (p. 30-31) differs grossly from that determined both by Baker (1961) and by me; (2) the type localities are only vaguely identified, and the name Molly Gibson does not appear on any published map of the region; and (3) the ammonites on which the age assignment is based are poorly preserved, no sutures are shown by any of the specimens (Stoyanow, 1949, p. 128), and no other diagnostic fossils are reported. For these reasons, Stoyanow's rock-stratigraphic names are not used in this report.

\section{BISBEE FORMATION}

Siltstone and mudstone with intercalations of limestone, sandstone, epiclastic volcanic sandstone and siltstone, and conglomerate in a triangular area of about 3 square miles in the northwest half of the UX Ranch block (fig. 2) were correlated by Hayes (1970b) with the Bisbee Formation of late Early Cretaceous age. These beds rest disconformably on silicic volcanic rocks which probably are of Triassic or Jurassic age. The total thickness of the sequence is not known inasmuch as the top is not present, outcrops are generally poor, and structural data are hard to obtain. A partial section nearly 1,400 feet thick has been measured, and a thickness of more than 3,000 feet is likely. The fine-grained rocks originally were probably brown, gray, or red but are now largely dark gray to black owing to contact metamorphism by Tertiary granodiorite.

The base of the Bisbee Formation is placed at the bottom of a bed of light-gray to gray or pinkishgray conglomerate that ranges in thickness from a few tens of feet to 300 feet or more. Just west of the UX Ranch the conglomerate rests on a conspicuous bed of grayish-red fine-grained silicic tuff and tuffaceous siltstone. The conglomerate is made up of subangular to rounded clasts as much as a foot across of silicic volcanic rocks in a sand or grit matrix. Most of the clasts are less than 2 inches across. In places the rock has a very sparse matrix and is a closely packed aggregate of pebbles and cobbles. Bedding is usually made evident by thin layers or pods of gray sandstone or purple to red sandy siltstone. The most abundant clasts are of light-gray to gray porphyritic rhyolite containing phenocrysts of quartz or feldspar or both minerals.

The basal conglomerate is overlain by dominantly fine-grained sedimentary rocks that are gray to grayish red in the eastern part of the outcrop area but grade to dark gray to nearly black in the western 
part, where they are intruded by granodiorite. Interlayered with these siltstones or mudstones are some gray, greenish-gray, or purplish-gray poorly sorted sandy or gritty beds. All these rocks commonly contain abundant epiclastic volcanic material, mainly fine-grained to devitrified glassy rocks. Except for the lower 100 feet or so, the rocks are poorly exposed, and the thickness is uncertain but is estimated to be $600-700$ feet. The basal part of the sequence is well exposed just west of the UX Ranch, and a generalized section of this part is shown in figure 4 .

Northwest of the UX Ranch this sequence is overlain by a lenticular bed of gray epiclastic volcanic conglomerate possibly as much as 100 feet thick. This conglomerate resembles the basal conglomerate in consisting of subrounded to rounded pebbles, cobbles, and boulders as much as a foot in diameter of silicic volcanic rocks in a coarse arkose matrix. Porphyritic rhyolite is the most abundant constituent; but fine-grained silicic tuff and lava are also common, and quartzite occurs sparingly.

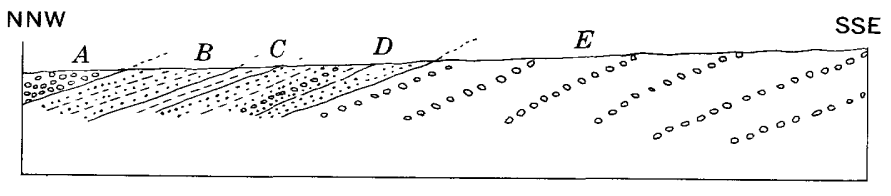

$$
\quad 100 \quad 200 \text { FEET }
$$

Figure 4.-Partial section of sedimentary and epiclastic volcanic rocks in the lower part of the Bisbee Formation west of the UX Ranch. Vertical scale equals horizontal scale. From youngest to oldest:

$A$, Gray pebble conglomerate.

$B$, Interbedded gray or light-purplish-gray sandstone and purplish-gray siltstone. Sandstone consists of angular to subrounded millimetersized grains of quartz, albite, and potassium feldspar, and a few of biotite, and larger grains of fine-grained to glassy volcanic rock, all set in a silty matrix. Siltstone is similar mineralogically but apparently contains much more volcanic glass debris.

$C$. Purplish-gray to grayish-red siltstone.
$D$, Gray, purplish-gray, or greenish-gray sandstone and grit with interbeds of dark-gray to purplish-gray siltstone and gray pebble con$E$, Gray pebble to cobble conglomerate.

The conglomerate is overlain by $800-900$ feet of very poorly exposed beds that seem to be mainly dark-gray to black fine-grained clastic rocks with minor light-gray to gray sandstone and arkose. At the top of this sequence is another bed of gray conglomerate as much as 20 feet thick. This conglomerate contains angular to rounded pebbles mostly less than one-half inch across of light-gray to darkgray dense fine-grained rocks of uncertain origin in a matrix of quartz sand and mud. Toward the east side of the outcrop area, the conglomerate grades to a light-brown coarse quartzite.

The only partial section of the Bisbee Formation suitable for measurement starts stratigraphically near-probably just above-this conglomerate. Inasmuch as this section contai: is rock types represen- tative of the whole formation, a detailed description is given. Because of structural complications and lack of outcrops, it was not possible to measure and include beds higher in the formation, but it is doubtful that any great additional thickness of beds is present.

Measured purtial section of Bisbee Formation

[Section begins near junction of the Patagonia-Washington Camp road and the old road to the Morning Glory mine; it ends about 4,000 ft N. $65^{\circ} \mathrm{W}$. of the Mowry mine. Location of section is shown in fig. 2]

Bisbee Formation:

Thickness

1. Sandstone, tuffaceous, gray to dark-gray, fine grained, thick bedded, pyritic; weathers brown, reddish brown, or light gray. Blocky outcrops. Bed 6 in. thick of highly fossiliferous gray limestone $12 \mathrm{ft}$ above base

2. No outcrops; canyon and old road to Morning Glory mine

3. Sandstone; like unit 1. Sparse thin beds of gray mudstone in lower part

4. No outcrops

5. Mudstone, dark-gray, hard, pyritic; weathers greenish gray to brown. Breaks down to very small rounded flakes.

6. Sandstone, white, light-gray, some brown; weathers to conspicuous mottled white and dark brown. Thick bedded ( $5 \mathrm{ft}$ ) with sparse silty partings. Breaks down to fine rubble. Bed 6 in. thick of fossiliferous dark-gray limestone $20 \mathrm{ft}$ above base

7. Sandstone, limy, dark-gray; weathers grayish brown

8. Mainly brown, light-gray, or white epiclastic volcanic sandstone; weathers brown. Poorly exposed

9. Sandstone, probably tuffaceous, light-gray to gray, fine-grained and equigranular, pyritic; weathers brown. Beds 1-2 ft thick, distinct. Highly jointed, breaks down to fine angular rubble; fragments typically have gray core enclosed in thin alternating white and brown rinds

10. Mudstone hornfels, dark-gray, pyritic, some slightly calcitic; weathers brown, reddish brown, or yellowish brown. Some very hard dense beds as much as 18 in. thick. Highly jointed, blocky outcrops break down to angular chips. Bed $1 \mathrm{ft}$ thick of dark-gray fossiliferous limestone $43 \mathrm{ft}$ above base

11. Limestone, dark-gray, massive; weathers gray. Irregular patches of silicic material stand out on weathered surfaces. Practically a coquina.

12. Mudstone, brown, purple, greenish-gray, poorly exposed. Some flaky mudstone, one bed $1 \mathrm{ft}$ thick of crossbedded greenish-gray sandy limestone, and several thin beds of shelly limestone. Becomes hard dark-gray to black hornfels toward top. At top, $3 \mathrm{ft}$ of hard limy and pyritic dark-gray siltstone hornfels.

13. Limestone, sandy, gray, hard; weathers cavernous. Irregular patches of pink siliceous limestone 
Bisbee Formation-Continued

Limestone unit 13 traced north to gully where section continues.

14. Mostly brown or purple soft siltstone and shale. Poorly exposed

15. Limestone, light-gray, coarse-grained, thinbedded. Interlayered light-brown limy sandstone that weathers light gray to tan. Lenticular; maximum thickness given. Abundant pelecypod fragments

16. Sandstone, light-brown, soft, impure; weathers light brown. Upper part is very limy sandstone that weathers lavender

17. Siltstone, light-gray; becomes shaly toward top..-

18. Limestone, light-gray, coarse-grained, recrystallized; weathers gray. Abundant poorly preserved pelecypods

19. Siltstone, slightly limy, light-gray, hard, distinctly bedded, pyritic

Covered area along gully; assumed to be along strike.

20. Siltstone; same as unit 19. Bed $10 \mathrm{ft}$ thick of purple mudstone $140 \mathrm{ft}$ above base

21. Sandstone, arkosic, light-brown; weathers rusty

22. Siltstone, limy, gray, hard, pyritic; weathers rusty

23. Siltstone, light-gray. Abundant irregular pods of gray slightly silty limestone that weathers very light gray.

24. Siltstone, light-gray, pyritic; weathers rusty. Obscure bedding, highly fractured. Sparse thin lenses of gray limestone that weathers light gray

25. Limestone, light-gray, fine-grained

26. Siltstone, light-gray, massive, pyritic, weathers rusty. Poorly exposed

27. Limestone conglomerate; pebbles of silty limestone mostly less than 1 in. across

28. Poorly exposed. Abundant chips of limestone and rusty-colored siltstone

29. Limestone, silty, purple, fine-grained, lenticular; weathers mottled purple and gray; breaks down to small angular fragments

30. Siltstone, light-gray, very poorly exposed; breaks down to abundant rusty-weathering chips. Bed $2 \mathrm{ft}$ thick of coarse sandstone $45 \mathrm{ft}$ above base, overlain by brown-weathering obscurely bedded siltstone that contains thin beds of gray-weathering limy siltstone. Bed $5 \mathrm{ft}$ thick of purple limy siltstone $95 \mathrm{ft}$ above base. Bed $3 \mathrm{ft}$ thick of gray arkose $105 \mathrm{ft}$ above base. Bed $5 \mathrm{ft}$ thick of light-greenish-gray silty limestone $120 \mathrm{ft}$ above base

31. Siltstone, limy, and shale, both purple and much fractured. Interlayered light-purplish-gray limy sandstone and purple silty limestone. Unit weathers mottled purplish red and white or gray. Some beds of hard fine-grained lightbrownish-gray sandstone or siltstone with films of epidote along fracture surfaces
4 43 205

Bisbee Formation-Continued

32. Light-gray fine-grained tuffaceous(?) rock that weathers variegated rusty color. Poorly exposed. Few thin beds of light-gray arkose that weathers brownish gray.

33. Siltstone, limy, and shale; like unit 31. Thin lenticular beds of purple fine-grained silty limestone with abundant small angular fragments of siltstone that stand out in relief on weathered surfaces

34. Limestone, silty, brown; weathers red and rusty brown. Some light-gray slightly sandy limestone that weathers brownish gray.

35. Siltstone, limy; like unit 31 . Cut by calcite seams

Total measured partial section of Bisbee Formation

Fault contact.

Bolsa Quartzite (Cambrian).

In the Patagonia Mountains the Bisbee Formation appears to contain considerably more volcanic material than it does elsewhere. Numerous rocks were identified in the field as having an appreciable volcanic component, or even as being volcanic ash, and more than half of the clastic rocks examined in thin section were feldspathic and had abundant finegrained matrix material resembling devitrified volcanic glass. However, few of these volcaniclastic rocks are believed to be of primary volcanic origin; rather, they are interpreted on the basis of texture and mineral composition as epiclastic and as derived from a predominantly volcanic terrane.

Very few limestone beds of the Bisbee are more than 10 feet thick, and most are traceable for only a few tens of feet. One bed, however, was traced with fair confidence for 3,000 feet. Commonly the limestone is dark gray and fine grained and contains abundant fragmental fossils; locally it has wavy thin silty or sandy layers.

In the southwest part of the outcrop area the Bisbee has been metamorphosed to hornfels by Tertiary granodiorite. A common feature of hornfelsed siltstone or mudstone is the presence of geodelike bodies as much as 8 inches in diameter that consist of an outer shell of light-green bleached-appearing hornfels, an intermediate shell of epidote and gypsum (?), and a tiny core of pyrite. The core and intermediate shell are frequently eroded, and only a green-rimmed depression is left on outcrop surfaces. These green spheroids are most abundant near the contact with granodiorite and become less abundant and finally disappear with distance from that contact. 


\section{FOSSILS AND AGE}

The limestone beds of the Bisbee Formation, and some of the siltstones as well, contain abundant fossils, but most of the fossils are highly fragmented and poorly preserved. No fossils clearly diagnostic of a more closely defined age than late Early Cretaceous have been reported previously, and none were found during this study.

Schrader $(1915$, p. 53) reported that fossils found "about half a mile northwest of Mowry" were identified by T. W. Stanton as Ostrea sp., a fragment of an ammonite probably belonging to the genus Acanthoceras, and fragments of bivalves, some of which appeared to belong to the family Chamidae. This fauna was assigned by Stanton to the Comanche Series, and the rocks were correlated by Schrader with the Bisbee Group of the Bisbee quadrangle, some 40 miles east.

Stoyanow (1949, p. 128-129) described three new species of ammonite from the upper part of the Molly Gibson Formation and placed them in the genus Stoliczkaia. On the basis of these fossils he correlated the Molly Gibson with the Del Rio Clay of Texas, which he considered to be of late Early Cretaceous age. However, as previously noted (p. E13), the fossils are poorly preserved and show no sutures, so their identity is uncertain.

A small collection (USGS colln. 29206) of pelecypods and gastropods from thin limestone beds near the junction of the Patagonia-Washington Camp road and the old road to the Morning Glory mine (SW1/4 sec. 16 (unsurveyed), T. 23 S., R. 16 E., Lochiel quadrangle) was reported by N. F. Sohl and R. W. Imlay to contain Arctica? sp., Gryphaea? sp., Trigonia cf. T. mearnsi Stoyanow, and Turritella sp. They stated (written commun., Sept. 13, 1965) :

The above-listed fossil assemblage cannot be definitively dated. The Trigonia is too poorly preserved to be positively identified but has coarsely noded ribs similar to T.mearnsi described by Stoyanow $(1949$, p. 78-79) from the Perilla Member of the Lowell Formation [of Stoyanow; in Bisbee Group, of late Early Cretaceous age]. The most abundant fossils in the collection are high-spired gastropods of the genus Turritella. All are rather small and either may represent a new species or may be immature forms of $T$. seriatimgranulata, a long-ranging species in Texas. At least they belong to this species group. Although Stoyanow figured no gastropods, he did mention that gastropods of this species group are numerous in the basal and topmost parts of the Lowell Formation. These remarks are meant to indicate only the possibility that your collections are pre-Washita, and better preserved material will be needed before we can do more.

Another collection (USGS Mesozoic loc. D3773) from dark-gray fine-grained limestone 3,400 feet south of American Peak (NW1/4 sec. 16 (unsurveyed), T. 23 S., R. 16 E., Lochiel quadrangle) contained only Serpula? sp., on which W. A. Cobban commented (written commun., June 19, 1962) : "The fossils seem to be calcareous worm tubes, but the preservation is not good. They indicate a marine environment but tell nothing of the age." These sparse faunal data indicate only a late Early Cretaceous age for the Bisbee Formation in the Patagonia Mountains. It seems likely, however, that the rocks are approximately equivalent to the Mural Limestone of the Bisbee Group in the Mule and Huachuca Mountains to the east and that they are of late Trinity to Fredericksburg age (Hayes, 1970a, p. A25).

\section{VOLCANIC ROCKS OF LOWER ALUM GULCH}

A sequence of dominantly light-colored silicic tuffs and lavas is exposed along lower Alum Gulch in the northwest corner of the Lochiel quadrangle and the northeast corner of the Nogales quadrangle (fig. 2 ). These rocks underlie an area about 2.5 miles long and as much as three-quarters of a mile wide. They probably overlie unconformably the volcanic and sedimentary rocks of the Flux mine area and are overlain unconformably or disconformably by the trachyandesite of Meadow Valley. The thickness of the Alum Gulch sequence is probably about 1,500 feet at most. Although the age is uncertain, the rocks are approximately parallel to the trachyandesite of Meadow Valley, of Late Cretaceous age, whereas they rest with angular unconformity on rocks of probable Triassic or Jurassic age; they are therefore thought to be Cretaceous rather than older.

The rocks in the lower part of the sequence are somewhat altered but retain enough original features to be identifiable as fragmental volcanic rocks and as volcanic conglomerate. Some rocks in the upper part are also little altered, but others, especially toward the northwest end of the outcrop area, are so thoroughly silicified, sericitized, or otherwise altered that their identity is doubtful.

The lowest rocks, between the Flux and Chief mines, are light gray, greenish-gray, or brownishgray silicic tuff breccia, tuff, welded tuff, volcanic conglomerate, and minor lava. The tuffs consist of phenocrysts $0.5-4 \mathrm{~mm}$ long of potassium feldspar, sodic plagioclase, quartz, and biotite and of abundant volcanic fragments, all enclosed in a finegrained base of mineral fragments and devitrified, locally spherulitic, glass shards and pumice. Vitroclastic textures are well preserved, and alteration to sericite, carbonate, epidote, and chlorite is slight. Lava interlayered with the volcaniclastic rocks is a 
greenish-gray porphyry composed of phenocrysts 1-3 mm long of pink potassium feldspar, albite, and chloritized biotite in a groundmass of devitrified and spherulitic glass that shows conspicuous flowage structure. This rock makes up at least one lava flow, and it also forms several small irregular intrusive bodies in the underlying older volcanic sequence. Volcanic conglomerate consists entirely of angular to rounded clasts as much as a foot across of silicic volcanic rocks in a generally sparse matrix.

The middle part of the Alum Gulch sequence is a lens-shaped mass of light-gray fine-grained porphyritic biotite latite (?) with conspicuous contorted flow layering. It forms very prominent rounded outcrops along Alum Gulch near the Worlds Fair mine. The latite body is about 1.5 miles long and as much as 1,000 feet thick and is interpreted as an extrusive lava dome. It consists of sparse small phenocrysts of sericitized plagioclase, now albite, and biotite completely altered to sericite and iron oxide, in a very dusty fine-grained groundmass of feldspar laths and devitrified glass.

The upper part of the sequence is made up of light-colored locally well-bedded tuff and less abundant silicic lava and flow breccia. These rocks consist mainly of devitrified glass with only sparse phenocrysts of feldspar. At one place where the upper part of the sequence directly overlies rocks of the Flux mine sequence, the basal rock is a coarse breccia that consists almost entirely of blocks as much as 5 feet across of pink porphyritic aplite and granite probably derived from Jurassic granitic rocks. In lower Alum Gulch the rocks are massive and sparingly porphyritic, and they have been thoroughly silicified, sericitized, epidotized, and pyritized. Many are finely brecciated. Most appear to be tuffs that consist largely of glass fragments devitrified to a very fine grained aggregate of feldspar and quartz. Some may be lavas but none was definitely identified as such.

The uppermost rocks, immediately underlying the trachyandesite of Meadow Valley, are white to lightgray vitric tuffs and subordinate lithic tuff.

\section{VOLCANIC ROCKS OF DOVE CANYON}

A heterogeneous sequence of dominantly volcanic and epiclastic volcanic rocks is exposed southwest of the Canelo Hills in upper Dove Canyon and in an unnamed canyon to the south (fig. 2). These rocks were referred to by Hayes and Raup (1968) as volcanic and sedimentary rocks of Jones Mesa but were not described. Hayes $(1970 \mathrm{~b}, \mathrm{p}$. B20) discussed the sequence briefly. The volcanics of Dove Canyon do not closely resemble any others in the report area, but they are about the same age, Late Cretaceous, as the trachyandesite of Meadow Valley and the Salero Formation of the Santa Rita Mountains to the north (Drewes, 1968, p. C11-C12).

The volcanics of Dove Canyon are exposed mainly along gully bottoms and have a very small outcrop area. Neither the base nor the top of the sequence is exposed, nor do exposures permit measurement of any continuous partial section. However, a thickness of at least 2,000 feet is likely. The Dove Canyon rocks are in fault contact with the Canelo Hills Volcanics. No other Mesozoic rocks are found nearby.

The volcanics of Dove Canyon comprise a varied group of volcanic conglomerate and mudflow, tuff and tuffaceous sandstone, andesitic lava flows, and agglomerate.

Epiclastic volcanic conglomerate is the most abundant rock type. It is made up largely or entirely of rocks other than those now exposed in the Canelo Hills; in particular, neither the widespread welded tuff unit of the Canelo Hills Volcanics nor its associated and easily recognized intrusive rhyolite porphyry is represented. Volcanic rocks are by far the most abundant components of the conglomerate, and among them andesitic rocks greatly predominate over more silicic types, and lavas predominate over tuffs. Clasts of sedimentary rocks-sandstone, quartzite, limestone, and dolomitic limestone-are sparse. Conglomerate boulders are rounded to subangular and are as much as 3 feet across. The conglomerate matrix is very heterogeneous and includes much volcanic glass and numerous lithic fragments together with feldspar, pyroxene, amphibole, biotite, quartz, and iron ore. Individual grains are of sand size or granule size and are somewhat rounded. Locally, pebbly tuff and tuffaceous sandstone are interbedded in the conglomerate.

Tuff and tuffaceous sandstone are second in abundance to volcanic conglomerate. The tuff varies considerably in appearance from place to place but commonly is a gray to pink or pale-red crystal-lithic variety, perhaps latitic or dacitic. Well-bedded waterlaid tuff is abundant. Most of the lithic components are silicic volcanic rocks, largely tuff and welded tuff, but some are white or gray quartzite.

A conspicuous north-trending bed of light-gray to buff coarse biotite latitic tuff crops out intermittently for about a mile north of Paloma Spring. The tuff dips $25^{\circ}-35^{\circ} \mathrm{W}$. and ranges in thickness from perhaps 125 feet at its northernmost exposure to at least 500 feet near Paloma Spring. It is separated from the underlying volcanic conglomerate by 5-30 feet of green or greenish-gray tuffaceous sandstone. 
East of Paloma Spring the lower part of the tuff contains abundant distinctive fragments of orange pumice. A modal analysis gives plagioclase $\left(\mathrm{An}_{30}\right)$, 28 percent; biotite, 5 percent; pumice fragments, 8 percent; accessory minerals (quartz, potassium feldspar, sphene, and iron ore), 2 percent; and matrix, 57 percent. The matrix consists of moderately welded and completely devitrified glass shards.

Lava flows are uncommon and make up only a few small outcrops. Those examined microscopically are gray to grayish-red augite or augite-hypersthene andesites.

Agglomerate was noted in only one place. It consists of completely unsorted partly rounded blocks of purple to grayish-green fine-grained to porphyritic andesite in a sparse matrix of greenish-gray glassy tuff. Most of the blocks are less than 3 feet across, but some are as much as 12 feet across.

Biotite from partly welded biotite latitic tuff at Paloma Spring has been dated radiometrically by the potassium-argon method at 72.0 m.y., or Late Cretaceous (S. C. Creasey, written communs., 1963, 1964). This age is the same as the potassium-argon age of biotite from welded tuff in the trachyandesite of Meadow Valley at Vaca Ranch, 7 miles to the northwest. Moreover, a tuff very similar lithologically to the dated rock from Dove Canyon underlies trachyandesite south of Vaca Ranch. The volcanics of Dove Canyon and the trachyandesite of Meadow Valley may thus be the lower and upper parts, respectively, of a single thick volcanic sequence.

\section{TRACHYANDESITE OF MEADOW VALLEY}

$A$ belt of trachyandesite ${ }^{1}$ and associated rocks several miles wide extends from the northeast part of the Patagonia Mountains eastward across Meadow Valley to the Canelo Hills, a distance of about 11 miles (fig. 2). These rocks are named informally for their extensive exposures in Meadow Valley. Most of the rocks are not very resistant to erosion, but some thick massive flows erode to steep slopes that have a local relief of 500-600 feet.

The trachyandesite ranges in thickness from a few feet at the west end of the outcrop area to possibly as much as 3,000 feet north and west of Harshaw. No section was found that would permit accurate measurement of the maximum thickness.

The trachyandesite rests unconformably on volcanic and sedimentary rocks of Cretaceous age and on silicic volcanic rocks of probable Triassic or Jurassic age. It is overlain unconformably by rhyolitic volcanic rocks of Cretaceous or Tertiary age, silicic tuff of middle Tertiary age (not shown on map), and alluvium of Tertiary and Quaternary age. About halfway between the Patagonia Mountains and the Canelo Hills, the trachyandesite is intruded by a stock of porphyritic monzonite of similar mineralogical composition. Both trachyandesite and monzonite are cut by numerous rhyolite necks and dikes; the conspicuous peak of Saddle Mountain is one of these necks.

The dominant rocks of the trachyandesite of Meadow Valley are gray to grayish-purple porphyritic lavas. Individual flows are a few tens of feet thick in the eastern and northern parts of the outcrop area but may attain thicknesses of 300-400 feet or more in the southwestern part in the Harshaw area. Tuff, tuffaceous standstone, welded tuff, rhyolite(?) and shale are minor components. For purposes of description, the trachyandesite is divided into three lithologic groups: tuff and shale of the Vaca RanchLittle Outfit Ranch area, thin lava flows in and west of Meadow Valley, and thick lava flows of the Harshaw-Trench Camp area.

\section{TUFF AND SHALE}

Between the Vaca Ranch and the Little Outfit Ranch the lowest part of the trachyandesite unit is a sequence of chloritic tuff, tuff, tuffaceous shale, shale, siltstone, and volcanic conglomerate at least 1,000 feet thick. Outcrops of these rocks are limited largely to gully floors, and therefore the stratigraphy and structural relations of the rocks are not entirely clear.

In the Little Outfit Ranch area the sequence appears to comprise a lower unit 100-150 feet thick of greenish-gray to gray medium- to coarse-grained tuff and sandy tuff, the base of which is not exposed; a middle unit 700-800 feet thick consisting mainly of gray to greenish-gray or yellow shale and siltstone, commonly tuffaceous; and an upper unit 350400 feet thick of grayish-green to light-brown finegrained tuff that contains some brown shale and tuffaceous shale and locally very abundant plant remains. Figure 5 is a sketch of a geologic section along a gully northeast of the Little Outfit Ranch, summarizing the lithology in this area; the section trends east-northeast. No lava flows are exposed along this traverse, but presumably the lowest flows would lie a few feet or, at most, a few tens of feet stratigraphically above the highest beds shown.

\section{Southwest of the Little Outfit Ranch, rocks of the}

\footnotetext{
1 Trachyandesite, as used in this report, denotes a volcanic rock with the potassium feldspar-plagioclase ratio of granodiorite (between 1:10 and 4:10) and with less than 10 percent quartz. It is thus intermediate between latite and andesite, and it is referred to by Nockolds (1954, p. 1008) as doreite; the name doreite, however, has not been widely used, and trachyandesite seems preferable.
} 


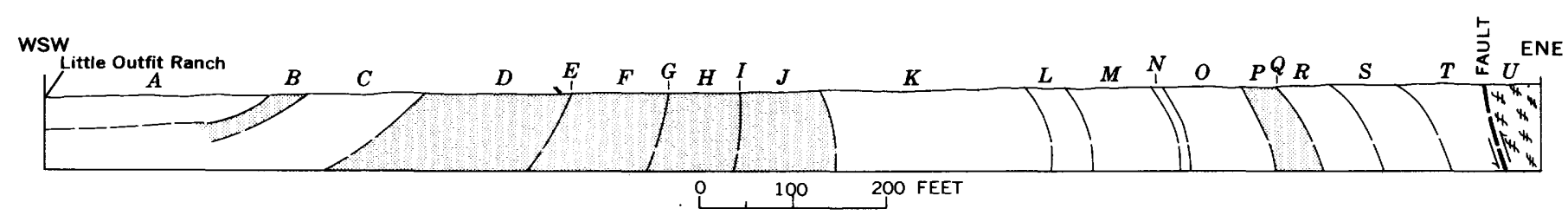

FIGURE 5.-Geologic section of volcanic and sedimentary rocks of the trachyandesite of Meadow Valley along a gully northeast of the Little Outfit Ranch. Units that do not crop out are shaded. From youngest to oldest:

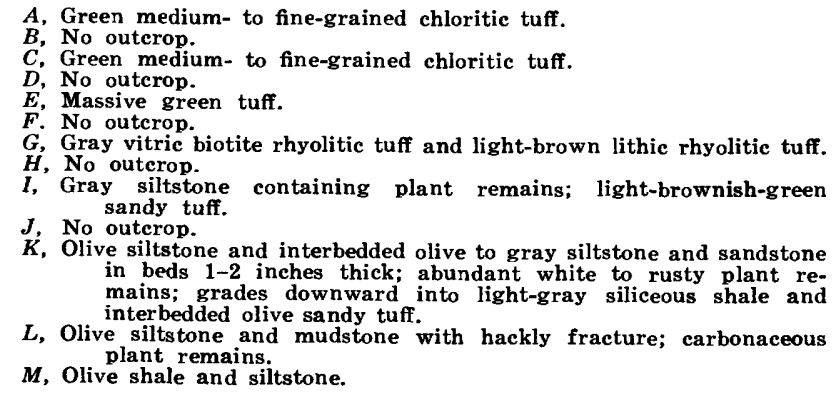

tuff-shale unit consist, from bottom to top, of wellbedded poorly sorted volcanic conglomerate with subrounded blocks as much as a foot across of purple porphyritic andesite in a matrix of green altered vitric tuff (base not exposed), green vaguely bedded palagonitic tuff with scattered blocks of purple andesite as much as 2 feet across, and light-gray to pinkish-gray massive vitric biotite rhyolitic tuff. Northeast of Vaca Ranch the unit includes a 1-foot-thick layer of red and green chert, and south of Vaca Ranch it contains a distinctive bed 10-15 feet thick of grayish-orange vitric rhyolitic tuff with abundant fragments of orange pumice; this tuff closely resembles a tuff in the volcanics of Dove Canyon near Paloma Spring (p. E17-E18).

\section{THIN LAVA FLOWS}

An extensive area in and west of Meadow Valley is underlain by a pile of thin flows of porphyritic trachyandesite and olivine andesite and subordinate flow breccia, welded tuff, rhyolitic(?) lava, and mudflow. The aggregate thickness of these flows is unknown but probably is several thousand feet. Most of the trachyandesites have phenocrysts of andesine and augite, but some have only feldspar phenocrysts. All are altered to some extent, and the pyroxene in most is extensively replaced by chlorite and carbonate. Olivine is invariably altered to iddingsite.

The basal flow of the sequence north of Little Outfit Ranch is a blackish-red very fine grained rock that is conspicuously flow layered. It contains sparse tiny phenocrysts of plagioclase almost entirely replaced by carbonate, as well as scattered grains of an altered green mafic mineral. The groundmass is

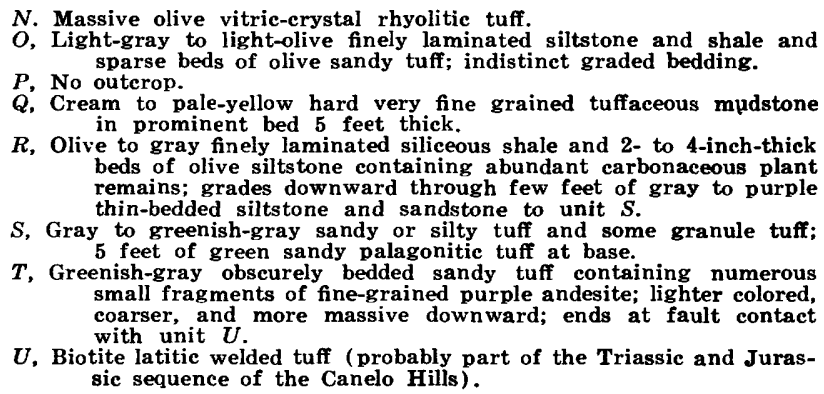
beds of olive siltstone containing abundant carbonaceous plant remains; grades downward through few feet of gray to purple

thin-bedded siltstone and sandstone to unit $S$.

$S$, Gray to greenish-gray sandy or silty tuff and some granule tuff; 5 feet of green sandy palagonitic tuff at base.

$T$, Greenish-gray obscurely bedded sandy tuff containing numerous small fragments of fine-grained purple andesite; lighter colored coarser, and more massive downward; ends at fault contact

$U$. Biotite latitic welded tuff (probably part of the Triassic and Jurassic sequence of the Canelo Hills).

a very dusty pale green mixture of glass and tiny plagioclase microlites that seem to be about $\mathrm{An}_{17}$ in composition.

In the Vaca Ranch area the lavas are very dusky red purple to olive-gray porphyritic pyroxene-olivine andesite. Some contain large vesicles lined with salmon-colored stilbite and clear heulandite. A typical rock has phenocrysts $3-4 \mathrm{~mm}$ across of andesine and augite, together with olivine phenocrysts less than $0.5 \mathrm{~mm}$ across, in an intersertal or trachytic matrix.

Some of the rocks are more silicic than trachyandesite. Southwest of Vaca Ranch, a low knob is capped by light-brownish-gray to pale-red porphyritic biotite-bearing lava, perhaps a latite, with highly contorted flow layering. The only phenocrysts are andesine and dusty biotite. The groundmass contains potassium feldspar, iron oxide, and devitrified glass. Just north of Vaca Ranch, a sheet of biotite latitic welded tuff is interlayered with lava flows. The welded tuff is 25-30 feet thick and is exposed for about 900 feet along the strike. It is a pale-red streaked rock that contains crystals of white feldspar and brown biotite, together with abundant lithic fragments (some of them porphyritic andesite) as much as $2 \mathrm{~cm}$ across, set in a stony matrix whose texture is distinctly eutaxitic. In thin section the rock is seen to contain plagioclase (about $A_{n}$ ), biotite, a little potassium feldspar, and partly collapsed pumice lentils in a matrix of partly devitrified glass shards that are only moderately welded.

Rocks that probably are silicic lavas, perhaps rhyolite or trachyte, form prominent outcrops over an area of about 1.5 square miles centered on a point about 1 mile west of Saddle Mountain. These 
rocks appear to be intercalated in, to rest on, and to intrude the trachyandesite, but contact relations are very obscure in most places, and indeed some silicic lavas may instead be highly altered trachyandesite. The rocks are varicolored-white, light gray, violet, or brown - and fine grained to sparsely porphyritic, and they weather to yellow, brown, or rust-colored cavernous outcrops. They generally are massive and featureless, and evidence for their origin is meager. Flow layering, breccia texture, and platy structure observed in a few places suggest that they are mostly lavas and flow breccias. Phenocrysts are small and invariably are completely altered to chalky aggregates whose shapes indicate that they were formerly feldspar. No other original mineral can be identified. The groundmass commonly is a patchy intergrowth of quartz and potassium feldspar that probably is devitrified glass. Alteration products include quartz, kaolin, alunite, sericite, iron oxides, and opal.

\section{THICK LAVA FLOWS}

In the area between Harshaw and Trench Camp, the lower part of the trachyandesite of Meadow Valley is made up of very thick massive coarse-grained lava flows that only here and there give any evidence of their origin. These flows closely resemble the monzonite north and northwest of Meadow Valley that is interpreted as being intrusive into trachyandesite, and indeed some of this monzonite may also be of extrusive origin.

Some of the flows appear to be $300-400$ feet thick, and one flow in the area west of the Hardshell mine may be at least twice that thick. Contacts between individual flows are obscure, however, and some contacts may have been overlooked. In the area southwest of Harshaw, flows are separated by variable thicknesses, commonly only a few feet, of purple or red vesicular lava that contains fewer phenocrysts than the overlying or underlying rock. Northeast of Trench Camp, thin layers of well-bedded red or green tuff are intercalated between flows. A very thick flow west-southwest of Harshaw is massive in its lower part and gradually becomes vesicular and amygdaloidal toward its top, the quartz-lined vesicles increasing upward in both number and size and attaining diameters of as much as $5 \mathrm{~mm}$. The transition from massive to amygdaloidal takes place through a thickness of about 70 feet.

No flow breccia was seen at the base of the sequence of thick trachyandesitic flows, and none is likely to be present inasmuch as the basal contact is fairly well exposed for about 1.5 miles between Hermosa Canyon and Harshaw Creek. No evidence of chilling of the trachyandesite or of alteration of the underlying rocks was found along this contact. As far as could be determined, the thick flows have about the same attitude as the underlying silicic volcanic rocks.

Typical coarse-grained trachyandesite 1,200 feet southwest of the Hardshell mine is a brownish-gray to grayish-red-purple rock that contains closely packed small phenocrysts of plagioclase and pyroxene. In thin section the plagioclase is seen to be very cloudy and near $\mathrm{An}_{20}$ in composition. Dark minerals are augite and aggregates of chlorite and iron oxide, probably pseudomorphs after biotite. Potassium feldspar and abundant apatite are interstitial to the phenocrysts.

\section{CHEMICAL COMPOSITION}

Chemical analyses, norms, and semiquantitative spectrographic analyses of four lavas believed to be representative of the trachyandesite unit are shown in table 3 , together with the analyses and norms of Nockolds' (1954) average doreite [= trachyandesite] and average rhyodacite.

The trachyandesites chemically resemble typical andesites except that they contain less lime and more alkalis and have a much higher ratio of $\mathrm{K}_{2} \mathrm{O}$ to $\mathrm{Na}_{2} \mathrm{O}$. Rocks of similar composition and of Late Cretaceous or Tertiary age are apparently widespread in southern Arizona. They include the Childs Latite of the Ajo region in western Pima County (Gilluly, 1946, p. 44-45), lavas in the Cloudburst Formation near San Manuel in Pinal County (Creasey, 1965 , p. 14-15), "turkey track" porphyry in the Twin Buttes quadrangle in Pima County and the Dragoon quadrangle in Cochise County (Cooper, 1961), lavas of the Demetrie Volcanics (Thoms, 1967) in the Twin Buttes quadrangle (J. R. Cooper, written commun., 1962), and lavas in the lower part of the Galiuro Volcanics in the Klondyke quadrangle (Simons, 1964, p. 71-72). Petrographically similar rocks have been noted in many other places in the region, and additional chemical analyses undoubtedly will reveal that some are trachyandesites.

\section{ALTERATION OF TRACHYANDESITIC LAVAS}

The trachyandesitic lavas of Meadow Valley are variably altered locally in a belt about 1 mile wide and 6 miles long along the west half of the north edge of the Lochiel quadrangle. Within this belt the lavas are pyritized and bleached, and they weather to light-gray to yellowish outcrops. Porphyritic texture may be faintly preserved or completely obliterated. Alteration appears to have occurred principally along steep-dipping fractures trending approximate- 
TABLE 3.-Comparison of chemical analyses, norms, and semiquantitative spectrographic analyses of trachyandesite and rhyodacite of Meadow Valley with those of Nockolds' (1954) average rocks

[Leaders (--) in figure columns indicate no data]

\begin{tabular}{|c|c|c|c|c|c|c|}
\hline \multicolumn{5}{|c|}{ Trachyandesite } & \multicolumn{2}{|c|}{ Rhyodacite } \\
\hline & \multicolumn{3}{|c|}{ Meadow Valley } & \multirow{2}{*}{$\frac{\begin{array}{c}\text { Nockolds' } \\
(1954) \\
\text { average }\end{array}}{4}$} & \multirow{2}{*}{$\begin{array}{c}\begin{array}{c}\text { Meadow } \\
\text { Valley }\end{array} \\
5 \\
159244\end{array}$} & \multirow{2}{*}{$\begin{array}{c}\begin{array}{c}\text { Nockolds' } \\
(1954) \\
\text { average }\end{array} \\
6\end{array}$} \\
\hline $\begin{array}{l}\text { Sample No.- } \\
\text { Lab. No-- }\end{array}$ & $\stackrel{1}{161448}$ & $\stackrel{2}{2}$ D110285W & $\stackrel{3}{161447}$ & & & \\
\hline \multicolumn{7}{|c|}{$\begin{array}{l}\text { Chemical analyses (percent) } \\
\text { (Analysts: Nos. 1, 2, 3, by P. L. D. Elmore, S. D. Botts, G. W. Chloe, Lowell } \\
\text { Artis, and H. Smith; 5, by P. L. D. Elmore, S. D. Botts, and G. W. Chloe) } \\
\end{array}$} \\
\hline $\begin{array}{l}\mathrm{SiO}_{2} \\
\mathrm{Al}_{2} \mathrm{O}_{3} \\
\mathrm{Fe} \mathrm{O}_{3} \\
\mathrm{FeO}_{3} \\
\mathrm{MgO} \\
\mathrm{CaO} \\
\mathrm{Na}_{2} \mathrm{O}_{\ldots} \\
\mathrm{K}_{2} \mathrm{O}_{2} \\
\mathrm{H}_{2} \mathrm{O} \\
\mathrm{H}_{2} \mathrm{O}+ \\
\mathrm{TiO}_{2} \\
\mathrm{P}_{2} \mathrm{O}_{5} \\
\mathrm{MnO} \\
\mathrm{CO}_{2}\end{array}$ & $\begin{array}{c}56.7 \\
18.9 \\
4.6 \\
.96 \\
2.6 \\
6.3 \\
3.8 \\
3.0 \\
.27 \\
.77 \\
.98 \\
.48 \\
.22 \\
<.05\end{array}$ & $\begin{array}{l}54.8 \\
16.8 \\
6.6 \\
2.0 \\
3.6 \\
6.0 \\
3.6 \\
3.0 \\
.33 \\
1.9 \\
1.2 \\
.36 \\
.14 \\
.14\end{array}$ & $\begin{array}{r}55.6 \\
15.9 \\
4.4 \\
4.0 \\
4.1 \\
5.1 \\
3.5 \\
3.4 \\
.2 \\
2.0 \\
1.2 \\
.3 \\
.1 \\
.09\end{array}$ & $\begin{array}{r}56.00 \\
16.81 \\
3.74 \\
4.36 \\
3.39 \\
6.87 \\
3.56 \\
2.60 \\
8 \\
6 \\
6 \\
6 \\
\\
\\
\end{array}$ & $\begin{array}{r}62.7 \\
17.3 \\
4.8 \\
.6 \\
1.1 \\
2.4 \\
4.5 \\
2.2 \\
1.0 \\
2.1 \\
1.1 \\
.3 \\
.0 \\
<.0\end{array}$ & $\begin{array}{r}66.27 \\
15.39 \\
2.14 \\
2.23 \\
1.57 \\
3.68 \\
4.13 \\
3.01 \\
-.08 \\
.68 \\
.17 \\
.07 \\
.0\end{array}$ \\
\hline $\begin{array}{c}\text { Sum - - } \\
\begin{array}{c}\text { Powder } \\
\text { density }\end{array}\end{array}$ & 100 & 100 & 100 & 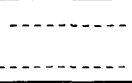 & 100 & \\
\hline \multicolumn{7}{|c|}{ Norms (percent) } \\
\hline $\begin{array}{l}\text { Q } \\
\text { or } \\
\text { ab } \\
\text { an } \\
\text { Con }\end{array}$ & $\begin{array}{r}7.7 \\
17.7 \\
32.1 \\
25.7\end{array}$ & $\begin{array}{r}6.8 \\
17.7 \\
30.4 \\
20.8 \\
-\end{array}$ & $\begin{array}{r}6.6 \\
20.1 \\
29.6 \\
17.6 \\
-\end{array}$ & $\begin{array}{r}7.2 \\
15.6 \\
29.9 \\
22.2\end{array}$ & $\begin{array}{r}22.6 \\
128 \\
38.3 \\
9.2 \\
4.2\end{array}$ & $\begin{array}{l}20.8 \\
17.8 \\
35.1 \\
14.5\end{array}$ \\
\hline fs & 6.5 & $\begin{array}{l}2.4 \\
9.0\end{array}$ & $\begin{array}{r}2.0 \\
10.2 \\
2.0\end{array}$ & $\begin{array}{l}4.1 \\
8.5 \\
3.0\end{array}$ & 2.7 & $\begin{array}{l}1.3 \\
3.9 \\
1.3\end{array}$ \\
\hline $\mathrm{hm}_{\mathrm{m}}$ & $\begin{array}{l}1.0 \\
3.9\end{array}$ & $\begin{array}{l}3.4 \\
4.2\end{array}$ & 6.4 & 5.3 & 4.8 & 3.0 \\
\hline il & $\begin{array}{l}1.9 \\
1.1\end{array}$ & $\begin{array}{r}2.3 \\
.9\end{array}$ & $\begin{array}{r}2.3 \\
.8\end{array}$ & $\begin{array}{r}2.4 \\
.8\end{array}$ & $\begin{array}{l}1.5 \\
1.0 \\
3\end{array}$ & $\begin{array}{r}1.4 \\
.3\end{array}$ \\
\hline $\mathrm{DI}_{1}$ & 57.5 & 54.9 & 56.3 & no data & 73.7 & no data \\
\hline
\end{tabular}

Semiquantitative spectrographic analyses (parts per million)

(Analysts: Nos. 1, 2, 3, by J. C. Hamilton; 5, by N. M. Conklin. 0, looked for but

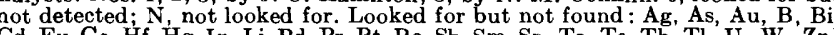
Cd, Eu, Ge, Hf, Hg, In, Li, Pd, Pr, Pt, Re, Sb, Sm, Sn, Ta, Te, Th, Tl, U, W, Zn)

\begin{tabular}{|c|c|c|c|c|}
\hline $\mathrm{Ba} \ldots$ & 0.15 & 0.1 & 0.2 & 0.1 \\
\hline$B \mathbf{e}_{\ldots}$ & .0002 & 0 & .00015 & .0002 \\
\hline $\mathrm{Ce}$. & 0 & 0 & 0 & .01 \\
\hline Co & .002 & .002 & .002 & .0015 \\
\hline Cr..... & .005 & .003 & .003 & 0 \\
\hline $\mathrm{Cu}$ & .02 & .02 & .007 & .0015 \\
\hline $\mathrm{Ga}_{-}$ & .003 & .003 & .003 & .005 \\
\hline $\mathrm{La}_{-}$ & .007 & .005 & .005 & .007 \\
\hline Mo. & 0 & 0 & 0 & $<.001$ \\
\hline $\mathrm{Nb}$. & .001 & .0015 & .001 & .001 \\
\hline Nd. & & & & .007 \\
\hline $\mathrm{Ni}$. & .005 & .0015 & .002 & .0007 \\
\hline $\mathrm{Pb}_{-}$ & .005 & .0015 & .01 & .002 \\
\hline $\mathrm{Se}_{--}$ & .0015 & .003 & .003 & .002 \\
\hline $\mathrm{Sr}_{-}$ & .15 & .07 & .07 & .1 \\
\hline V. & .03 & .03 & .03 & .02 \\
\hline $\mathrm{Y}$ & .003 & .003 & .005 & .005 \\
\hline Yb & $\mathrm{N}$ & .0005 & $\mathrm{~N}$ & .0005 \\
\hline & .02 & .015 & .015 & .05 \\
\hline
\end{tabular}

1 Differentiation index

SPECIMEN DESCRIPTIONS

1. Trachyandesite. Thin flow of porphyritic lava, 1.1 mile S. $23^{\circ} \mathrm{W}$. of Saddle Mountain. Mode: Plagioclase (An 45), 33 percent; clinopyroxene, 4 percent biotite, 4 percent; iron ore, 1 percent; other, 1 percent; groundmass, 57 percent.

Trachyandesite. Thin flow of porphyritic lava $3,000 \mathrm{ft}$ west-northwest of Harshaw. Rock consists of sodic plagioclase and clinopyroxene with minor

potassium feldspar. iron ore, quartz, and apatite.

rachyandesite. Thick holocrystalline lava flow 1 mile southwest of Harshaw. Rock consists of sodic plagioclase, clinopyroxene, potassium feldspar, chlorite, and sparse quartz.

4. Average doreite ( $=$ trachyandesite). Nockolds (1954, p. 1018, table 5, col. 2). yodacite or dacite. Thin fine-grained lava flow 1,000 ft north-northwest Little Outfit Ranch. col. 4). ly east but also follows fractures of other orientations. Contacts between altered and unaltered rock are irregular and sharp, and dark unaltered remnants commonly are preserved within lighter colored altered rock, so the nature of the original rock is seldom in doubt. In the partially altered rock, plagioclase is wholly replaced by sericite and kaolinite, and the devitrified glass of the groundmass is very dusty and nearly opaque. In more strongly altered rock, phenocrysts are entirely converted to a light-brown dusty clay mineral, perhaps montmorillonite, or to gypsum; in some rocks only vague outlines of phenocrysts remain. The most intensely altered rocks are white, and they weather rust colored; apparently they consist almost entirely of sericite and silica.

\section{AGE}

Biotite from biotite latitic welded tuff intercalated in trachyandesitic lava just north of Vaca Ranch was dated radiometrically by the potassium-argon method at 72.1 \pm 2.2 m.y. (R. F. Marvin, H. H. Mehnert, and Viola Merritt, written commun., 1966). No field evidence was found to indicate any appreciable age differences among the rocks composing the trachyandesite of Meadow Valley, and therefore the unit is assigned a Late Cretaceous age.

A nearly identical age (72.5 \pm 2.2 m.y.) has been reported for biotite from the welded tuff member of the Salero Formation in the southern Santa Rita Mountains (Drewes, 1968, p. C11-C12). The two formations thus appear to be approximate temporal equivalents, but they differ markedly in lithology and clearly represent separate volcanic-sedimentary episodes.

\section{CRETACEOUS OR TERTIARY ROCKS} VOLCANIC ROCKS OF THE HUMBOLDT MINE-TRENCH CAMP AREA

An area of a little more than 1 square mile lying west of the Humboldt mine and Trench Camp is underlain by silicic volcanic rocks, mostly thickbedded coarse tuff. The rocks are very resistant to erosion and form a rugged terrain with steep slopes and abundant conspicuous knobby outcrops. The relations of these rocks with the surrounding rocks are very complex. The northwest, west, and southwest boundaries are probably faults or silicified fault zones. The contact on the east and southeast is an unconformity along which the silicic tuffs overlie the trachyandesite of Meadow Valley and older rocks of the American Mine, UX Ranch, and Thunder Mine blocks of the southern Patagonia Mountains. The Humboldt mine-Trench Camp volcanic rocks are at least 800 feet thick, and the maximum thickness is 
probably not much greater. No direct evidence of age is available, but the rocks rest unconformably on the trachyandesite of Meadow Valley, of Late Cretaceous age, and are altered and mineralized. Inasmuch as mineralization in southeastern Arizona is generally considered to be of Late Cretaceous or early Tertiary age, the rocks are probably no younger; therefore, they are tentatively assigned a Cretaceous or Tertiary age.

The rocks consist of both thick-bedded crudely layered subaerial lapilli tuff, tuff breccia, and block breccia and well-bedded and locally channeled waterlaid tuff and pebbly tuff, as well as a little silicic lava. They are cut by several irregularly shaped breccia masses, one about 1,200 feet long, that probably are volcanic necks, and they are traversed by numerous highly silicified zones, including a very large one that forms the southwest border for about 2,000 feet. The rocks everywhere are sericitized to some extent, and in the southern one-third of the outcrop area they are considerably alunitized.

The tuffs and lapilli tuffs are light-gray rocks that contain phenocrysts of one or more of the minerals quartz, feldspar, and biotite in a devitrified and very dusty matrix that commonly shows only a vague vitroclastic texture. Northeast of the Chief mine, the tuffs have conspicuous phenocrysts of quartz as much as $3 \mathrm{~mm}$ across, together with phenocrysts of potassium feldspar and completely sericitized biotite. In the Humboldt mine area the tuffs have only highly sericitized phenocrysts of feldspar and biotite.

The tuff breccias are massive rocks which consist of various-sized volcanic fragments in a matrix that in some rocks is recognizably vitroclastic but in others is merely a fine-grained irresolvable aggregate, probably mostly devitrified glass. Some of these rocks are obscurely bedded, but most show no evidence of bedding. Northwest and west of Trench Camp the breccias consist of fragments 1-6 inches across in a very dusty matrix in which the only recognizable mineral grains are quartz. Other breccias have grains of feldspar as well as quartz, and rarely they contain fragments of quartzite.

A prominent vulcanian block breccia on the east side of the outcrop area is a chaotic jumble of partly rounded red to grayish-red blocks of silicic lava, lapilli tuff, and sandy tuff as much as 3 feet across. The sparse matrix material is darker red and fragmental.

Lavas appear to be mainly on lower slopes along Alum Gulch. They are light-gray rocks that contain small phenocrysts of quartz and a little sericitized biotite, together with sparse lithic fragments, in a very fine grained groundmass of quartz and sericite that shows no evidence of original vitroclastic texture and presumably is massive devitrified glass.

The abundance of breccias and coarse tuffs suggasts a nearby source for the volcanic rocks, as do also the several volcanic necks within the outcrop area and the rhyolitic dikes that cut both the volcanics and the trachyandesite of Meadow Valley immediately to the east.

\section{VOLCANIC ROCKS OF RED MOUNTAIN}

Red Mountain is a prominent irregular mountain mass about 3 miles southeast of Patagonia. The south flank of this mountain, the only part in the report area, appears to be made up of massive silicic volcanic rocks. These rocks are very resistant to erosion and form steep, in places cliffy, slopes. They overlie the trachyandesite of Meadow Valley; although the contact is nowhere clearly exposed, it is probably an unconformity. The attitude of the volcanics is uncertain, but the basal contact, although irregular, is roughly horizontal, and the few structural data available also suggest near horizontality. The thickness is estimated at about 1,500 feet and may be somewhat more; the original thickness has been reduced an unknown amount by erosion. The volcanic rocks of Red Mountain are all highly altered and locally mineralized and are considered to be about the same age as the volcanic rocks of the Humboldt mine-Trench Camp area-that is, Cretataceous or Tertiary.

The volcanics of Red Mountain are white, lightgray, or pinkish-gray to pale-red thick-bedded very fine grained and, in general, rather featureless rocks that weather to various hues of brown and red. Only rarely do they provide any clues to their origin. Although both lava flows and tuffs were tentatively identified in the field, microscopic study of seven rocks confirmed the identity of only one, a lava; original textures in the rest have been completely destroyed by devitrification or other alteration. The rocks commonly contain sparse completely altered phenocrysts of feldspar and biotite, but they may also be nonporphyritic. Flow layering was recognized in only a few places, and possible bedding was found at only one place.

The source area of the volcanics of Red Mountain is not known. Several dikes of similar lithology half a mile or more long cut the trachyandesite of Meadow Valley south of Red Mountain, and they or similar dikes beneath Red Mountain may have been feeders. One possible volcanic vent was recognized in the volcanics near their south edge. 


\section{REFERENCES CITED}

Baker, R. C., 1961, The geology and ore deposits of the southeast portion of the Patagonia Mountains, Santa Cruz County, Arizona: Michigan Univ. unpub. Ph. D. thesis, $287 \mathrm{p}$.

Cooper, J. R., 1961, Turkey-track porphyry-A possible guide for correlation of Miocene rocks in southeastern Arizona: Arizona Geol. Soc. Digest, v. 4, p. 17-33.

Creasey, S. C., 1965, Geology of the San Manuel area, Pinal County, Arizona with a section on Ore deposits, by J. D. Pelletier and S. C. Creasey: U.S. Geol. Survey Prof. Paper 471, 64 p.

Drewes, Harald, 1968, New and revised stratigraphic names in the Santa Rita Mountains of southeastern Arizona: U.S. Geol. Survey Bull. 1274-C, 15 p.

Gilluly, James, 1946, The Ajo mining district, Arizona: U.S. Geol. Survey Prof. Paper 209, 112 p. [1947]. Supp., 1949, 1 p., new pl. $21 \mathrm{~A}$, revised sections of pls. 20,22 , and 23 .

Hayes, P. T., 1970a, Mesozoic stratigraphy of the Mule and Huachuca Mountains, Arizona: U.S. Geol. Survey Prof. Paper 658-A, $28 \mathrm{p}$.

$-1970 \mathrm{~b}$, Cretaceous paleogeography of southeastern Arizona and adjacent areas: U.S. Geol. Survey Prof. Paper 658-B, $42 \mathrm{p}$.

Hayes, P. T., Simons, F. S., and Raup, R. B., 1965, Lower Mesozoic extrusive rocks in southeastern Arizona-The Canelo Hills Volcanics: U.S. Geol. Survey Bull. 1194-M, $9 \mathrm{p}$.

Hayes, P. T., and Raup, R. B., 1968, Geologic map of the Huachuca and Mustang Mountains, southeastern Arizona: U.S. Geol. Survey Misc. Geol. Inv. Map 1-509.
Imlay, R. W., 1944, Correlation of Lower Cretaceous formations of the Coastal Plain of Texas, Louisiana, and Arkansas: U.S. Geol. Survey Oil and Gas Inv. (Prelim.) Chart 3.

Nockolds, S. R., 1954, Average chemical compositions of some igneous rocks: Geol. Soc. America Bull., v. 65, no. 10, p. 1007-1032.

Schrader, F. C., 1915, Mineral deposits of the Santa Rita and Patagonia Mountains, Arizona, with contributions by J. M. Hill: U.S. Geol. Survey Bull. 582, 373 p.

Shapiro, Leonard, and Brannock, W. W., 1962, Rapid analysis of silicate, carbonate, and phosphate rocks: U.S. Geol. Survey Bull. 1144-A, 56 p.

Simons, F. S., 1964, Geology of the Klondyke quadrangle, Graham and Pinal Counties, Arizona: U.S. Geol. Survey Prof. Paper 461, $173 \mathrm{p}$.

Simons, F. S., Raup, R. B., Hayes, P. T., and Drewes, Harald, 1966, Exotic blocks and coarse breccias in Mesozoic volcanic rocks of southeastern Arizona, in Geological Survey Research 1966: U.S. Geol. Survey Prof. Paper 550-D, p. D12-D22.

Stoyanow, A. A., 1937, Fossiliferous zones in the Cretaceous and Tertiary deposits of Southeastern Arizona [abs.]: Geol. Soc. America Proc., 1936, p. 296-297.

1949, Lower Cretaceous stratigraphy in southeastern Arizona: Geol. Soc. America Mem. 38, 169 p.

Thoms, J. A., 1967, The geology and ore deposits of the Tascuela area, Sierrita Mountains, Pima County, Arizona [abs.] : Dissert. Abs., Sec. B, v. 27, no. 7, p. 2420B-2421B. 